\title{
Tsunami hazard potential for the equatorial southwestern Pacific atolls of Tokelau from scenario-based simulations
}

\author{
Alan R. Orpin, Graham J. Rickard, Peter K. Gerring, and Geoffroy Lamarche \\ National Institute of Water and Atmospheric Research (NIWA), Private Bag 14-901, Kilbirnie, Wellington, New Zealand \\ Correspondence to: Alan R. Orpin (alan.orpin@niwa.co.nz)
}

Received: 14 January 2015 - Published in Nat. Hazards Earth Syst. Sci. Discuss.: 30 July 2015

Revised: 26 February 2016 - Accepted: 4 April 2016 - Published: 31 May 2016

\begin{abstract}
Devastating tsunami over the last decade have significantly heightened awareness of the potential consequences and vulnerability of low-lying Pacific islands and coastal regions. Our appraisal of the potential tsunami hazard for the atolls of the Tokelau Islands is based on a tsunami source-propagation-inundation model using Gerris Flow Solver, adapted from the companion study by Lamarche et al. (2015) for the islands of Wallis and Futuna. We assess whether there is potential for tsunami flooding on any of the village islets from a selection of 14 earthquake-source experiments. These earthquake sources are primarily based on the largest Pacific earthquakes of $M_{\mathrm{w}} \geq 8.1$ since 1950 and other large credible sources of tsunami that may impact Tokelau. Earthquake-source location and moment magnitude are related to tsunami-wave amplitudes and tsunami flood depths simulated for each of the three atolls of Tokelau. This approach yields instructive results for a community advisory but is not intended to be fully deterministic. Rather, the underlying aim is to identify credible sources that present the greatest potential to trigger an emergency response.

Results from our modelling show that wave fields are channelled by the bathymetry of the Pacific basin in such a way that the swathes of the highest waves sweep immediately northeast of the Tokelau Islands. Our limited simulations suggest that trans-Pacific tsunami from distant earthquake sources to the north of Tokelau pose the most significant inundation threat. In particular, our assumed worst-case scenario for the Kuril Trench generated maximum modelledwave amplitudes in excess of $1 \mathrm{~m}$, which may last a few hours and include several wave trains. Other sources can impact specific sectors of the atolls, particularly distant earthquakes from Chile and Peru, and regional earthquake sources to the
\end{abstract}

south. Flooding is dependent on the wave orientation and direct alignment to the incoming tsunami.

Our "worst-case" tsunami simulations of the Tokelau Islands suggest that dry areas remain around the villages, which are typically built on a high islet. Consistent with the oral history of little or no perceived tsunami threat, simulations from the recent Tohoku and Chile earthquake sources suggest only limited flooding around low-lying islets of the atoll. Where potential tsunami flooding is inferred from the modelling, recommended minimum evacuation heights above local sea level are compiled, with particular attention paid to variations in tsunami flood depth around the atolls, subdivided into directional quadrants around each atoll. However, complex wave behaviours around the atolls, islets, tidal channels and within the lagoons are also observed in our simulations. Wave amplitudes within the lagoons may exceed $50 \mathrm{~cm}$, increasing any inundation and potential hazards on the inner shoreline of the atolls, which in turn may influence evacuation strategies. Our study shows that indicative simulation studies can be achieved even with only basic field information. In part, this is due to the spatially and vertically limited topography of the atoll, short reef flat and steep seaward bathymetry, and the simple depth profile of the lagoon bathymetry.

\section{Introduction}

The potentially disastrous consequences of tsunami on lowlying islands and coastlines has only been reinforced in the aftermath of recent great earthquakes, namely Sumatra in 2004, Tonga-Samoa in 2009, and Tohoku (Japan) in 2011. Atolls have very low topographic relief, emerging only me- 


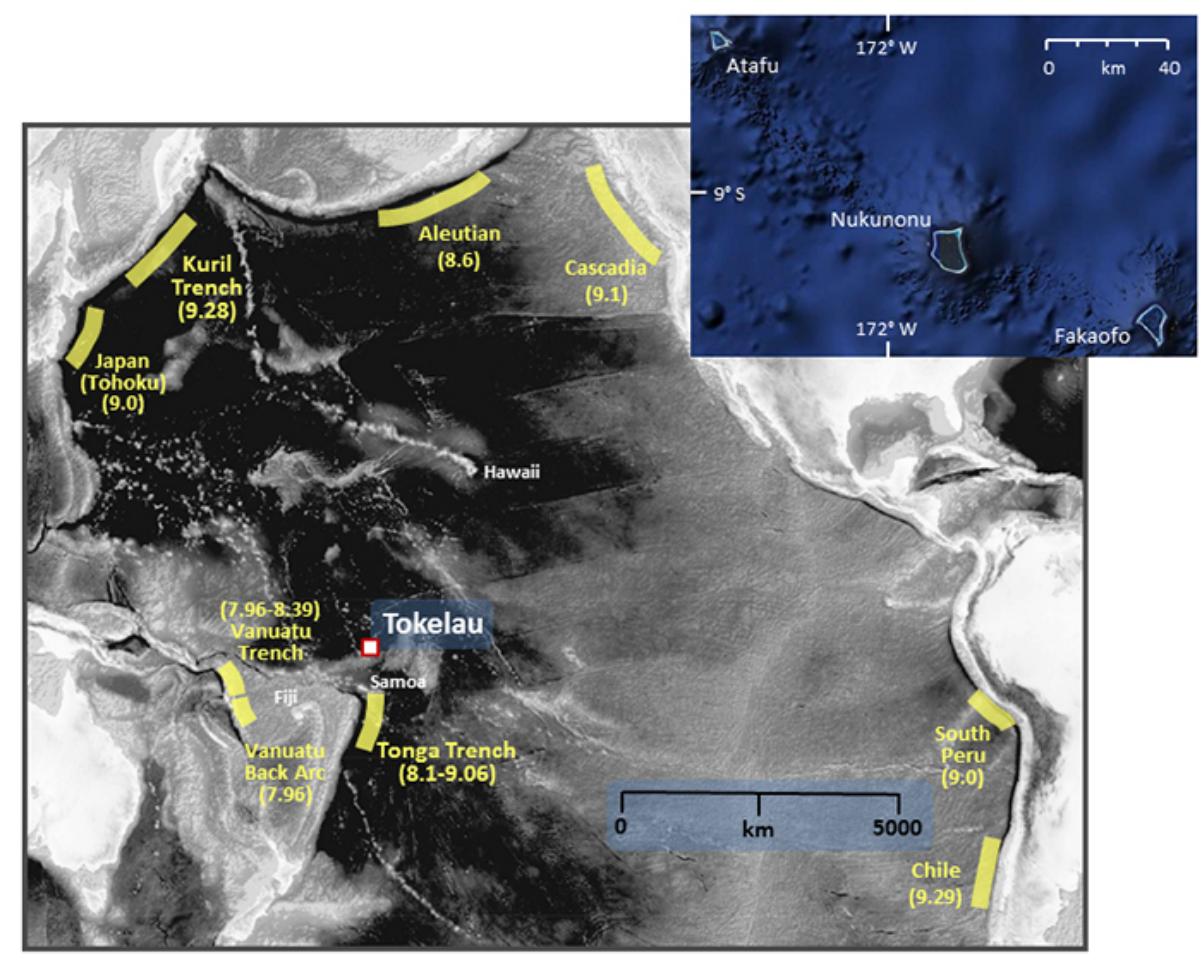

Figure 1. Location of the Tokelau Islands in the equatorial southwestern Pacific. The location of the atolls of Tokelau (Atafu, Nukunonu, and Fakaofo) are shown in the inset (base image from Google Earth). Known seismogenic sources are shown as light yellow bars, and their earthquake magnitudes used in the selected simulations herein are indicated (also summarized in Table 2 along with the fault-rupture geometries).

tres above sea level (e.g. Woodroffe, 2008), such that even small rises in water level from storm set-up or tsunami may inundate lagoon-facing coastlines during spring tides (Ford et al., 2014). In this context, inhabitants of atolls face different challenges from those of larger bedrock islands and mainland coasts, not least of which the lack of topographic relief, and in turn, potential limitations to emergency evacuation procedures. In addition, the characteristic deep-ocean surrounds and steep approaches of atolls result in tsunami behaviour that differs from coastlines rimmed by shallow shelves (Sladen et al., 2007; Ford et al., 2014). Such rapid changes in depth on the approaches, a narrow reef crest and tidal platform, tidal channels, very thin or irregularly shaped islets, and a central lagoon that can be broad and deep, present computational challenges to the simulation of tsunami behaviour at resolutions meaningful for hazard assessments.

A suite of studies from the atoll islands of the Maldives documented the immediate impact of the tsunami generated from the Sumatran earthquake (e.g. Kench et al., 2006, 2008), along with sedimentological and morphological evidence from previous events that extend back millennia (Klostermann et al., 2014). Throughout the Indian Ocean, the Sumatran earthquake also demonstrated a lack of community understanding of the threat posed by tsunami, appropriate re- sponse plans, and the broader societal impacts (e.g. Kurita et al., 2007). The severity of the impact from such events has been a catalyst for international efforts to better understand and quantify tsunami hazards. However, many small-island nations are largely subsistence economies without the infrastructure to develop assessments of tsunami hazard.

Islands within the South Pacific are surrounded by distant seismogenic subduction margins with a history of great earthquakes capable of generating trans-Pacific tsunami (e.g. Hébert et al., 2001a, b). Regionally, the Southwest Pacific also has a history of intense tectonic activity, originating from the Pacific-Australia convergent plate boundary and the broad area of deformation in the North Fiji Basin-Lau Basin. There are numerous tectonically complex features associated with the Tonga and Vanuatu subduction zones (Pelletier et al., 1998) and recent studies have documented evidence of tsunami impacts resulting from regional sources (e.g. Lamarche et al, 2010). The atolls of Tokelau lie $\sim 700 \mathrm{~km}$ north of the tip of the Tonga-Kermadec Trench (Fig. 1).

Tokelau is also one of five Pacific Island nations being supported under the New Zealand government's Ministry for Civil Defence and Emergency Management (MCDEM) Pacific Tsunami Risk Management Project, which focuses on implementing key country disaster management priorities, early warning systems, public education, and national exer- 
cises. To address that need, NIWA undertook an initial appraisal using a limited series of selected numerical simulations of tsunami inundation hazard for Tokelau, by exploring whether tsunami from distant or regional earthquake sources represent a significant threat. This approach is adopted to yield indicative and instructive results rather than being fully deterministic. The results are intended to help each Village Emergency Committee form their specific predetermined response to tsunami warnings disseminated from the Pacific Tsunami Warning Centre in Hawaii via the government of Tokelau, and to help ensure that emergency responses to tsunami warnings are efficient and that any evacuations are not undertaken unnecessarily.

Our investigation closely follows a companion study by Lamarche et al. (2015), which examines tsunami hazards in the remote French territory of Wallis and Futuna, Southwest Pacific, using the Gerris Flow Solver to numerically model tsunami generation, propagation, and inundation. We adapt Gerris to create a series of scenarios, which are not necessarily comprehensive, generated by earthquakes originating from the seismogenic Pacific Rim, the sources of which have been identified and characterized in the literature. Both studies build on the Gerris modelling work pioneered by Popinet (2012) that simulated the 11 March 2011 Japan (Tohoku) tsunami.

\section{Study area}

Tokelau is located just south of the equator, and consists of three relatively small atolls ("nukus") that span approximately $160 \mathrm{~km}$ along a southeast-northwest axis, covering a total land area of approximately $12.25 \mathrm{~km}^{2}$ within an Exclusive Economic Zone (EEZ) of $290000 \mathrm{~km}^{2}$. The islands are located between $8^{\circ} 33^{\prime} \mathrm{S}, 172^{\circ} 30^{\prime} \mathrm{W}$ (Atafu), and $9^{\circ} 21^{\prime} \mathrm{S}$, $171^{\circ} 12^{\prime} \mathrm{W}$ (Fakaofo), with Nukunonu approximately midway (Fig. 1). Tokelau is located $\sim 480 \mathrm{~km}$ north of Samoa. All three atolls have a lagoon surrounded by a continuous matrix of fringing reef with the landmass, above on the reef flat, made up of a series of islets. These are typically not more than a few hundred metres wide, and between 3 and $5 \mathrm{~m}$ above mean sea level at their highest point. The tidal range in the Tokelau region is around $0.7 \mathrm{~m}$. Tropical cyclones and El Niño-Southern Oscillation (ENSO)-driven droughts are the two most common natural hazards affecting Tokelau at sub-decadal timescales. As far as we are aware there is no recorded or oral history of significant inundation damage on any of the atolls of Tokelau that can be attributed to distant or regional tsunami.

Tokelau's population is currently just below 1500 , split between the three atolls. On Atafu and Nukunonu there is a single village, whereas on Fakaofo the population is split between two islets (Fale and Fenua Fala). The villages are all located on the leeward (western or northwestern) sides of the atolls.
Adjacent to the villages, narrow passages $<30 \mathrm{~m}$ wide are cut through the reef matrix to the open ocean. Around all the villages, short gabion and concrete walls $\sim 2-3 \mathrm{~m}$ high protect the beach rise below houses and infrastructure. Concrete sea walls and gabions 3-4 m high are also used to reinforce small inlets and wharfs, such as on Fale on Fakaofo.

\section{Assessing tsunami flooding for Tokelau: scope and limitations}

A number of studies have assessed deep water tsunami hazard around the Pacific Islands and Southwest Pacific, for example the first-generation tsunami scenario database developed for the Australian region by the Commonwealth Scientific and Industrial Research Organisation (CSIRO) as part of the Joint Australian Tsunami Warning Centre (Greenslade et al., 2009). However, deep-water tsunami models alone are not sufficient to develop an understanding of whether there is a potential tsunami inundation threat, particularly on atolls such as Tokelau where the seafloor rises very steeply from depths of between 2000 and $3000 \mathrm{~m}$ to the edge of the fringing reef at the sea surface.

In the current study, modelling has been limited to distant and regional sources, where typically a warning would be provided by the Pacific Tsunami Warning Center. While tsunami caused by local submarine landslides or volcanismrelated slope failure are other potential hazards, landslides big enough to cause any significant and widespread tsunami flooding will be rare and infrequent (e.g. Hébert et al., 2002; Goff, 2011). In addition, any consideration of slope instabilities in general will require near-complete coverage of highresolution multibeam bathymetry of the slope surrounds. For Tokelau, and many other islands in the South Pacific, these data are not sufficiently dense, but as multibeam-bathymetry coverage continues to improve, local tsunami sources should also be examined. As such, local slope failures are not considered in the current study.

The tsunami inundation assessment is based on applying a tsunami source-propagation-inundation model to estimate whether there is potential for inundation of any of the village islets (motus) from a range of potential distant and regional tsunami sources. This assessment for Tokelau followed a four-step workflow.

1. For each tsunamigenic-source area, simulate the maximum potential tsunami based on a series of the very large, plausible earthquakes from published fault displacement and historical data (cf. Lamarche et al., 2015).

2. Explore the relationship between an earthquake warning $\left(M_{\mathrm{w}}\right.$ and source location) and a potential tsunami threat (tsunami-wave amplitude, $H_{\max }$, and tsunamiflood depths, $\left.H_{\text {in }}\right)$. 
3. Identify those source regions that pose a greater threat and report these separately from other compiled sources.

4. Where potential tsunami flooding is identified, compile recommended evacuation heights above local sea level, with particular attention to variations in tsunami-flood depth around the atolls.

\section{Data sets and methods}

\subsection{Topographic and bathymetric data}

The veracity of numerical simulations of tsunami is strongly dependent on the quality of seafloor topographic (bathymetric) data and the land topographic data for the area of inundation. The tsunami inundation modelling relied on an integrated representation of the nearshore bathymetry and topography drawn from available data sources. As noted in other modelling studies of island nations in the equatorial Pacific, whilst the paucity of high-resolution data is a critical limitation, first-order quantification of tsunami behaviour and hazard assessments are still possible (e.g. Sladen et al., 2007). As such, maps of tsunami-inundation extent or tsunami-flood depths produced in the current study should be seen as indicative only, and more attention should be given to patterns outlining the possible tsunami-wave run-up over the emergent land.

Regional bathymetry from the General Bathymetric Chart of the Oceans data sets (GEBCO; www.gebco.net) is used to create the generalized bathymetry. Limited high-resolution multibeam-bathymetric data from selected reef passages and approaches $(<300 \mathrm{~m}$ water depth) were acquired by the Royal New Zealand Navy Littoral Warfare Support Group in Tokelau for the Ministry of Foreign Affairs and Trade during Exercise Tropic Twilight in July 2011 (Jensen, 2011). These data are incorporated into a regional bathymetric grid, along with soundings collected in 2005 and 2007 by the Navy, for the upper slope and mid-slope around all three atolls. We use remotely sensed depth information from colour satellite images to complement these bathymetric data and to better parameterize the lagoons, reef flats, and aprons. Hand-editing was required with iterative model runs to ensure that sensible bathymetric profiles were achieved.

A significant limitation for Tokelau is the lack of highresolution topography over the emergent landmass and adjacent tidal shallows. Elevation information for the atolls, islets, and emergent reefs are generated from a range of unprocessed data sources, all of which required careful filtering. Vector data (generated from airborne radar) and feature catalogue information from the Multinational Geospatial CoProduction Programme (MGCP) and the New Zealand Defence Force (NZDF) are at a $30 \mathrm{~m}$ grid spacing and are incorporated where applicable. However, given the very low elevation of the atolls, extensive and careful hand-editing of the elevation spot heights is essential to ensure sensible elevations are incorporated into the topographic grid surface. For example, treetops were often listed as the land elevation, and the spot-height density was often too low to create the spatial resolution required to model the villages and surrounds meaningfully. Other elevation information is gleaned from spot heights for features or infrastructure (e.g. tidal datum), rectified satellite images from the NZDF, and other published sources (e.g. Google Earth).

Due to the low-data density around the villages, these elevation data are complemented by manual input of spot heights estimated from satellite images, following known natural bathymetric features such as beach rock, reef flats, or the beach face, along with manmade features such as sea walls where elevations could be estimated from field photographs. No surveyed, independent vertical (tidal) datum exists for Tokelau, so our simulations at mean sea level (m.s.l.) are created from assumed reference heights drawn from our interpretation of what limited geomorphological information exists. To achieve a workable spot-height density, the fringing-reef edge is assigned a height of $0 \mathrm{~m}$, approximating a model datum for m.s.l., both on the seaward and lagoon sides of the atolls. This assumption appears compatible with the small number of available cross sections of Tokelau village atolls from McLean (1993). An example of the final spot-height data density used in the simulations from the village of Atafu is shown in Fig. 2. To represent a possible "worst-case scenario" in terms of initial water height, a model sea-level datum is set at m.s.l. $+1 \mathrm{~m}$ to simulate a tsunami arriving at Mean High Water Spring tide (MHWS), visible as a MHWS strandline in aerial photographs that spatially approximates the base of the beach rise. Additional simulations at other presumed tidal elevations are unwarranted given the uncertainties.

The modelled topography for Atafu at m.s.l. and MHWS can be portrayed as a colour-ramp contour map (Fig. 3). Tsunami-wave height and tsunami-flood depths cannot be extrapolated linearly from any given sea level because of the complex behaviour of the wave interacting with the atoll as it shoals. A measure of the tsunami-wave run-up over the emergent land (a proxy for inundation flooding) is termed $H_{\text {in }}$. This differs from the maximum wave amplitude, $H_{\max }$, above a given sea level (m.s.l. or MHWS). We anticipate that the two complete sets of simulations herein capture a range of realistic model outcomes and provide an indicative portrayal of the likely tsunami behaviour and threats for Tokelau. A schematic depiction of the sea-level elevations and inundation terminology used in the tsunami model simulations is shown in Fig. 4.

\subsection{Tsunamigenic-earthquake scenarios and fault models}

For the purposes of exploring the civil threat posed by tsunami for Tokelau, the tsunami-generating earthquake 
Table 1. Largest Pacific earthquakes and the approximate location of their epicentres since 1900 and Pacific earthquakes of $M_{\mathrm{W}} \geq 8.1$ since 1950 (in order of decreasing magnitude). Data from USGS (see http://earthquake.usgs.gov/earthquakes).

\begin{tabular}{|c|c|c|c|c|}
\hline Date (dd/mm/yyyy) & Latitude (dec deg) & Longitude (dec deg) & $M_{\mathrm{W}}$ & Comment \\
\hline $22 / 05 / 1960$ & $38.29^{\circ} \mathrm{S}$ & $73.05^{\circ} \mathrm{W}$ & 9.5 & Valdivia, Chile \\
\hline 28/03/1964 & $61.02^{\circ} \mathrm{N}$ & $147.65^{\circ} \mathrm{W}$ & 9.2 & Prince William Sound, Alaska \\
\hline 04/11/1952 & $52.76^{\circ} \mathrm{N}$ & $160.06^{\circ} \mathrm{E}$ & 9.0 & Kamchatka \\
\hline $11 / 03 / 2011$ & $38.322^{\circ} \mathrm{N}$ & $142.369^{\circ} \mathrm{E}$ & 9.0 & Tohoku, near the east coast of Honshu, Japan \\
\hline $31 / 01 / 1906$ & $1^{\circ} \mathrm{N}$ & $81.5^{\circ} \mathrm{W}$ & 8.8 & Colombia-Ecuador \\
\hline $27 / 02 / 2010$ & $35.846^{\circ} \mathrm{S}$ & $72.719^{\circ} \mathrm{W}$ & 8.8 & Offshore Maule, Chile \\
\hline $04 / 02 / 1965$ & $51.21^{\circ} \mathrm{N}$ & $178.5^{\circ} \mathrm{W}$ & 8.7 & Rat Islands, Aleutian Arc, Alaska \\
\hline 09/03/1957 & $51.56^{\circ} \mathrm{N}$ & $175.39^{\circ} \mathrm{W}$ & 8.6 & Andreanof Islands, Aleutian Arc, Alaska \\
\hline 03/02/1923 & $54^{\circ} \mathrm{N}$ & $161^{\circ} \mathrm{E}$ & 8.5 & Kamchatka \\
\hline $13 / 10 / 1963$ & $44.9^{\circ} \mathrm{N}$ & $149.6^{\circ} \mathrm{E}$ & 8.5 & Kuril Islands \\
\hline $23 / 06 / 2001$ & $16.264^{\circ} \mathrm{S}$ & $73.641^{\circ} \mathrm{W}$ & 8.4 & Near the coast of south Peru \\
\hline $06 / 11 / 1958$ & $44.329^{\circ} \mathrm{N}$ & $148.623^{\circ} \mathrm{E}$ & 8.3 & Kuril Islands \\
\hline $19 / 08 / 1977$ & $11.085^{\circ} \mathrm{S}$ & $118.464^{\circ} \mathrm{E}$ & 8.3 & South of Sumbawa, Indonesia \\
\hline 04/10/1994 & $43.773^{\circ} \mathrm{N}$ & $147.321^{\circ} \mathrm{E}$ & 8.3 & Kuril Islands \\
\hline $25 / 09 / 2003$ & $41.815^{\circ} \mathrm{N}$ & $143.91^{\circ} \mathrm{E}$ & 8.3 & Hokkaido, Japan region \\
\hline $15 / 11 / 2006$ & $46.592^{\circ} \mathrm{N}$ & $153.226^{\circ} \mathrm{E}$ & 8.3 & Kuril Islands \\
\hline 04/05/1959 & $53.351^{\circ} \mathrm{N}$ & $159.645^{\circ} \mathrm{E}$ & 8.2 & Near the east coast of Kamchatka \\
\hline $16 / 05 / 1968$ & $40.903^{\circ} \mathrm{N}$ & $143.346^{\circ} \mathrm{E}$ & 8.2 & Off the east coast of Honshu, Japan \\
\hline $11 / 08 / 1969$ & $43.478^{\circ} \mathrm{N}$ & $147.815^{\circ} \mathrm{E}$ & 8.2 & Kuril Islands \\
\hline $17 / 02 / 1996$ & $0.891^{\circ} \mathrm{S}$ & $136.952^{\circ} \mathrm{E}$ & 8.2 & Irian Jaya region, Indonesia \\
\hline 04/03/1952 & $42.5^{\circ} \mathrm{N}$ & $143^{\circ} \mathrm{E}$ & 8.1 & Hokkaido, Japan region \\
\hline $17 / 10 / 1966$ & $10.807^{\circ} \mathrm{S}$ & $78.684^{\circ} \mathrm{W}$ & 8.1 & Near the coast of central Peru \\
\hline $10 / 01 / 1971$ & $3.132^{\circ} \mathrm{S}$ & $139.697^{\circ} \mathrm{E}$ & 8.1 & Papua, Indonesia \\
\hline 03/10/1974 & $12.254^{\circ} \mathrm{S}$ & $77.524^{\circ} \mathrm{W}$ & 8.1 & Near the coast of central Peru \\
\hline 22/06/1977 & $22.878^{\circ} \mathrm{S}$ & $175.9^{\circ} \mathrm{W}$ & 8.1 & Tonga region \\
\hline $12 / 12 / 1979$ & $1.598^{\circ} \mathrm{N}$ & $79.358^{\circ} \mathrm{W}$ & 8.1 & Near the coast of Ecuador \\
\hline $13 / 01 / 2007$ & $46.243^{\circ} \mathrm{N}$ & $154.524^{\circ} \mathrm{E}$ & 8.1 & East of the Kuril Islands \\
\hline 01/04/2007 & $8.466^{\circ} \mathrm{S}$ & $157.043^{\circ} \mathrm{E}$ & 8.1 & Solomon Islands \\
\hline $29 / 09 / 2009$ & $15.489^{\circ} \mathrm{S}$ & $172.095^{\circ} \mathrm{W}$ & 8.1 & Samoa Islands region \\
\hline
\end{tabular}

sources can be classified into two basic scenarios based on event records: (1) regional sources that would have limited warning (a few hours) requiring a rapid response; and (2) distant sources that cause trans-Pacific events, which would allow sufficient time for verification that a tsunami has occurred and appropriate warnings to be given. The earthquake scenarios selected in the current study are based on the largest Pacific earthquakes of $M_{\mathrm{w}} \geq 8.1$ since 1950. (Table 1). To be capable of generating a tsunami large enough to reach Tokelau and other Southwest Pacific Islands, oceanwide or regional earthquakes would typically have to be of magnitude greater than $M_{\mathrm{W}}=8.0$. From this historical compilation, a selection of modelling scenarios of credible sources of tsunami that may impact Tokelau is considered (Table 2). These earthquake sources are longstanding and many have led to well-documented and measured tsunamigenic events elsewhere in the Pacific (e.g. National Geophysical Data Centre, 2016). Palaeo-tsunami research from the Pacific Islands indicates that there is substantial geological evidence for destructive tsunami events with millennial-scale reoccurrence intervals (Goff et al, 2001a).
Tsunami propagation is controlled by seafloor topography and water depth along the path of the tsunami-wave train, while inundation is controlled by the coastal bathymetry, reef structures, topography above the shoreline, and human modification (e.g. Kunkel et al., 2006; Gelfenbaum, 2011; Popinet, 2012). Key physical parameters of the earthquake sources influence the amplitude of the tsunami wave at transoceanic distances, including focal depth, total slip and slip area, and azimuth (e.g. Hébert et al., 2001b). The final amplitude at a receiving shore is also strongly affected by focusing and defocusing effects, due to variations in bathymetry along the path of the tsunami (e.g. Hébert et al., 2001a).

The current study considers only those tsunami generated by seafloor displacements associated with earthquake fault ruptures. Tsunami excitation increases proportionally with the vertical displacement of the fault rupture on the seafloor, which in turn is related to the moment magnitude $\left(M_{\mathrm{W}}\right)$ of the generating earthquake (e.g. Okal, 1988) and the dip of the fault. Moment magnitude can be derived from an estimate of the fault rupture's physical parameters (length, width, depth, 
Table 2. Compilation of plausible worst-case earthquake scenarios based on a combination of the largest historical earthquakes and/or established earthquake fault models (after Lamarche et al., 2015). The rake angle is $90^{\circ}$ for all sources.

\begin{tabular}{llllllll}
\hline Name & Based on & $M_{\mathrm{W}}^{2}$ & $\mathrm{~L}^{3}(\mathrm{~km})$ & $\mathrm{W}^{4}(\mathrm{~km})$ & $\mathrm{Slip}^{5}(\mathrm{~m})$ & Dip $\left(^{\circ}\right)$ & Strike $\left.^{\circ}\right)$ \\
\hline Regional sources & & & & & & & \\
\hline North Vanuatu Trench & worst case & 8.39 & 400 & 40 & 10 & 30 & 350 \\
Vanuatu - back arc & worst case & 7.96 & 200 & 30 & 6 & 40 & 170 \\
South Vanuatu Trench & worst case & 8.24 & 300 & 40 & 8 & 30 & 335 \\
Tonga Trench & worst case & 9.06 & 1000 & 80 & 20 & 30 & 195 \\
Tonga 2009 & 29 Sep 2009 & 8.1 & $200^{* *}$ & $50^{* *}$ & $5-9.5^{* *}$ & 57 & 342.5 \\
Tonga Trench + 1 m & worst case & 9.06 & 1000 & 80 & 20 & 30 & 195 \\
North Tonga Trench & worst case & 8.16 & 300 & 40 & 6 & 60 & 100 \\
Central Tonga Trench & worst case & 8.57 & 600 & 50 & 10 & 30 & 200 \\
\hline Trans-Pacific distant sources & & & & & & 12 & 195 \\
\hline Japan (Tohoku) & 11 Mar 2011 & 9.0 & 700 & $50 *$ & 12.5 & 12 & 010 \\
Chile & 22 May 1960 & 9.29 & 920 & 120 & 32 & 12 & 305 \\
Peru & 13 Aug 1868 & 9.0 & 900 & 150 & 15 & 20 & 15 \\
Aleutian Arc & 9 Mar 1957 & 8.6 & 850 & 150 & 10 & 15 & 350 \\
Cascadia & worst case & 9.1 & 1050 & 70 & 17.5 & 15 & 350 \\
Kuril Trench & worst case & 9.28 & 1000 & 200 & 17 & 30 & 220 \\
\hline
\end{tabular}

(1) date of earthquake used as reference; (2) magnitude calculated in the model, likely to differ from that of the reference earthquake; (3) fault length; (4) fault width; (5) length of slip along fault plane; $\left({ }^{*}\right)$ estimate after Popinet (2012) using a complex sub-fault model based on seismic inversion; and (**) estimate from composite USGS model; see http://earthquake.usgs.gov/earthquakes/eqinthenews/2009/us2009mdbi/finite_fault.php.

and dip) using empirical relationships (e.g. Wells and Coppersmith, 1994). Earthquake moment magnitudes are calculated from empirical correlations with fault rupture lengths and widths using the Hanks and Kanamori (1979) empirical regression to estimate the fault rupture parameters:

$M_{\mathrm{W}}=\frac{2}{3} \log \left(M_{\mathrm{o}}\right)-10.7$.

The seismic moment $\left(M_{\mathrm{O}}\right)$ is calculated from

$M_{\mathrm{o}}=\mu \mathrm{LWD}$

where the rigidity modulus of the Earth's crust $(\mu)$ is $3 \times 10^{11}$ dyne $\mathrm{cm}^{-2}$, the fault length (L), and width (W) are determined from bathymetry maps and literature review, and the verge slip (event displacement) along the fault plane (D) is derived from published literature. No errors are assigned to these dimensions as we consider them to be maximum values. However, the relationship between earthquake magnitude and seafloor vertical displacement is complex, and in the absence of well-constrained field measurements may have multiple solutions and carry significant uncertainties (e.g. Okada, 1985). These uncertainties are not formally quantified herein and are beyond the scope afforded by the current study.

Earthquake parameterization herein (Table 2) is adapted from that described in the companion paper by Lamarche et al. (2015) from a scenario-based study of tsunami hazard for the South Pacific Islands of Wallis and Futuna. Parameters are obtained from the literature and knowledge of regional tectonics and geodynamics (e.g. Johnson and Satake, 1993; Wesson et al., 2007; Lamarche et al., 2010, 2015; Shao et al., 2011; Goff et al., 2011b, 2012). Very large, plausible earthquakes for each seismogenic region are estimated as a first-order guide to assess potential tsunami behaviour, supported by observational data where possible, e.g. recorded tsunami events in Hawaii and around the Pacific. In most cases these earthquake scenarios follow historic precedents, primarily since the mid-1950s and modern quantitative methods of source parameterization. However, for some established sources that are not well constrained by recent giant megathrust earthquakes $\left(\geq M_{\mathrm{W}}=9.0\right.$ ), compelling evidence over the last $100+$ years warrant the development of worstcase scenarios to better characterize a potential tsunami hazard for Tokelau. Note that there are inherent complexities when modelling great earthquakes, and as highlighted by Greenslade et al. (2009), linear scaling becomes unreliable beyond $M_{\mathrm{W}}=9.2$ and results in unrealistic earthquake rupture and slip lengths because peak slip occurs over a reduced area.

Earthquake fault parameters are compiled for the distant circum-Pacific deep subduction trenches of Japan, Kuril Islands, Aleutian Islands, Cascadia, Peru, and Chile, where earthquake magnitudes $\geq M_{\mathrm{w}} 8.5$ have been recorded (Table 1, Fig. 1). Data describing these historical earthquakes and tsunami are readily available from the United States Geological Survey (earthquake.usgs.gov) and $\mathrm{Na}-$ tional Oceanic Atmospheric Administration (www.ngdc. noaa.gov) databases. Of particular relevance to the current 


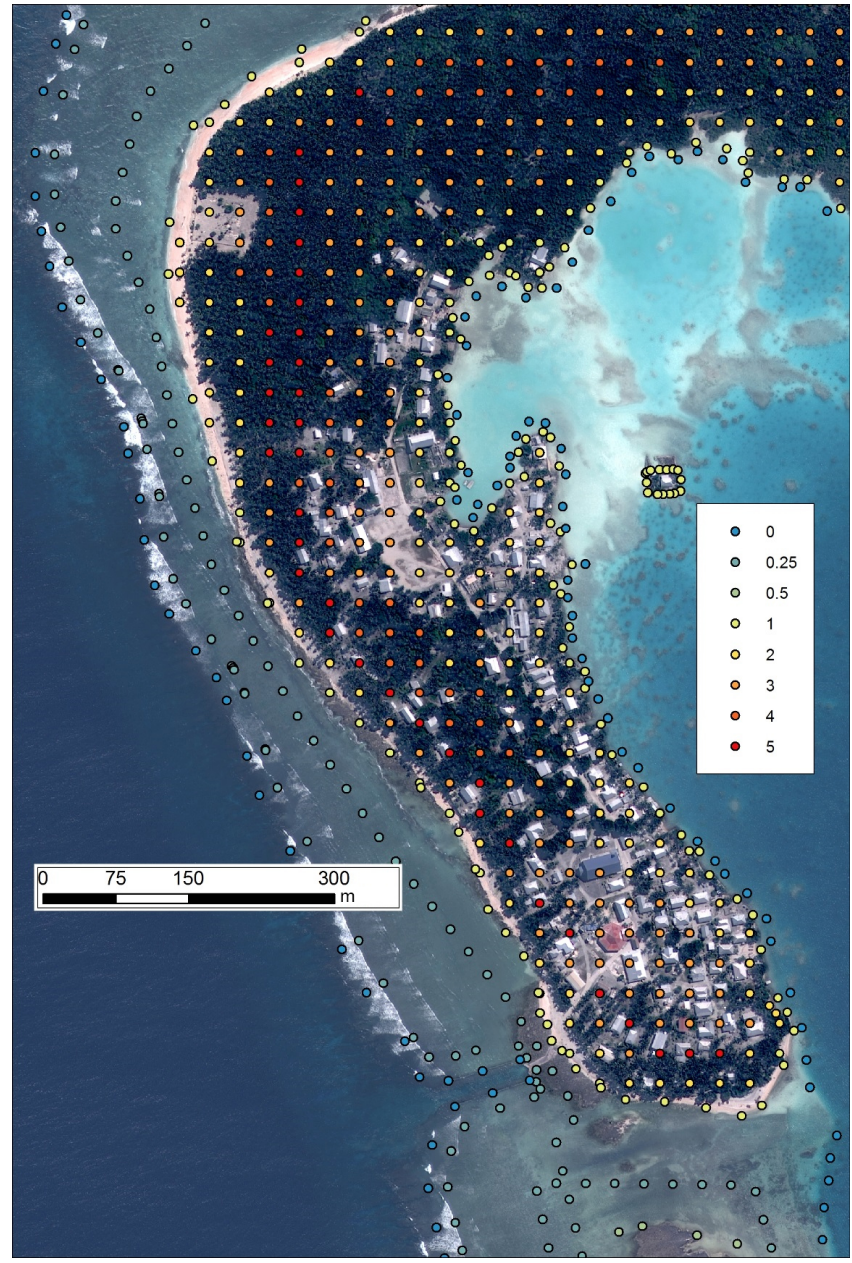

Figure 2. Example of derived spot-height data (in metres) with a grid spacing of $\sim 30 \mathrm{~m}$ for a selected area around Atafu village. These new elevation (depth) data are used in the tsunami simulations.

study are the very active, distant subduction-margin sources to the north and northeast of Tokelau, namely the Tohoku, Kuril, and Aleutian Trench sources.

The Tohoku fault parameters are based on the welldocumented 11 March $2011 M_{\mathrm{w}}=9.0$ earthquake, the resulting tsunami from which is simulated in detail in Popinet (2012). The source model compiles 190 sub-faults previously defined by Okada (1985), and obtained by seismic inversion (Shao et al., 2011). Hence, the average slip noted in Table 2 is only a summary of this information.

For the Kuril Islands and Kamchatka, the fault parameters are developed from two well-documented earthquakes described by Rabinovich et al. (2008): (1) $M_{\mathrm{w}}=8.3$ earthquake of 15 November 2006, the epicentre of which was located on the continental slope and had a $400 \mathrm{~km}$ long rupture; and (2) $M_{\mathrm{w}}=8.1$ earthquake of 13 January 2007 which was located in Kuril-Kamchatka Trench and had a $200 \mathrm{~km}$ long rupture. Both these earthquakes caused trans-Pacific
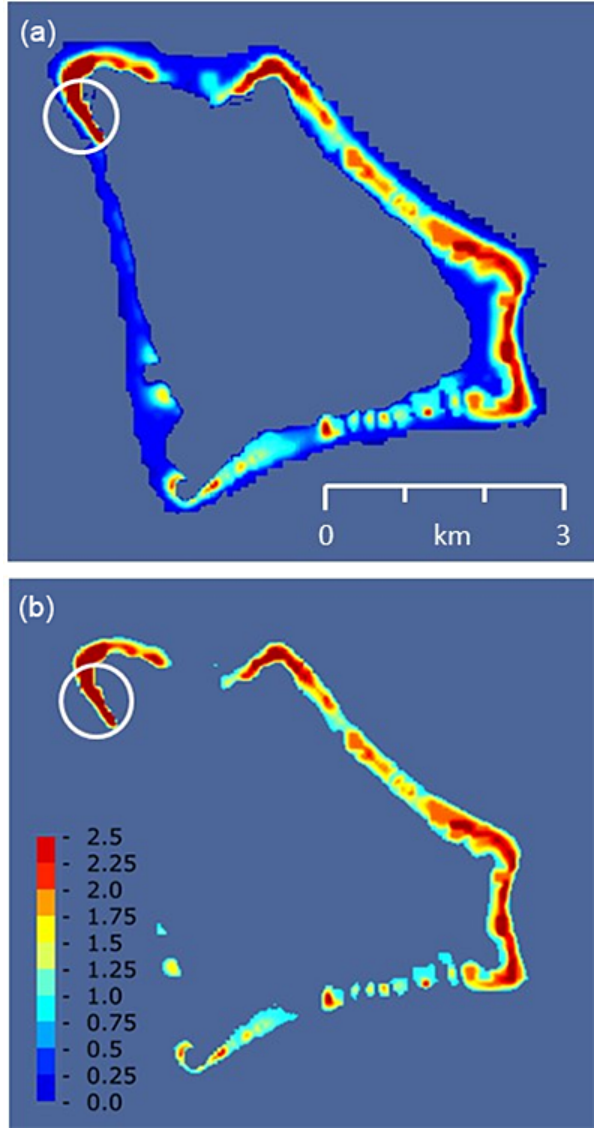

Figure 3. Example of the model-generated topography for Atafu, the smallest and northernmost atoll of the Tokelau group. The land topography is in metres above mean sea level (m.s.l.) (a), and at Mean High Water Spring (MHWS) (b), at a regular spatial resolution of $15 \mathrm{~m}$. In the time-dependent tsunami runs, the adaptive grid in Gerris will evolve and select the appropriate grid dimensions consistent with the tsunami wave as it approaches and subsequently passes the islands. The vertical land heights span a relatively limited range of $0.25-5 \mathrm{~m}$. In contrast the surrounding ocean ranges from around zero at the reef edge to thousands of metres' water depth within a short distance seaward of the shoreline. The lagoons have inferred depth ranges spanning many tens of metres (no verified measured depths were available). The village of Atafu is indicated by the circle in the northwestern corner of the atoll.

tsunamis that were recorded in Japan, Aleutian, Hawaii, along the west coast of North America, Peru, Chile, and New Zealand. A larger $M_{\mathrm{w}}=8.8-9.0$ earthquake occurred in 1952 on the northern portion of the Kuril-Kamchatka margin which also generated a severe and locally damaging transPacific tsunami. Early analysis by Bath and Benioff (1958) estimated that the aftershock sequence was distributed over an area $1030 \mathrm{~km}$ in length and $240 \mathrm{~km}$ in width, but subsequent studies suggest a smaller rupture area, approximately $700 \mathrm{~km}$ long and 150-200 km wide (e.g. Ben-Menahem and Toksöz, 1963), and more complex slip behaviour along fault segments (Johnson and Satake, 1999; MacInnes et al., 2010). 


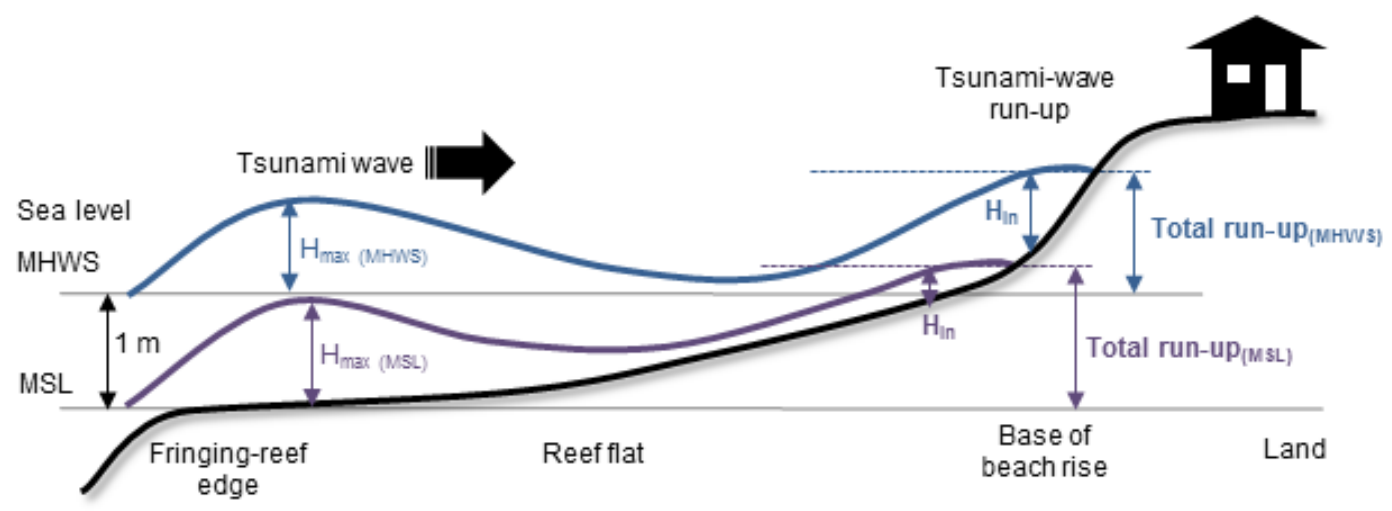

Figure 4. Schematic depiction of model sea levels used in the tsunami simulations and terminology used to quantify tsunami-wave inundation. The horizontal and vertical dimensions are not to scale.

Data and technology limitations from 1952 result in large uncertainties with any reanalysis. Nonetheless, the great length of the Kuril-Kamchatka subduction margin and its propensity to produce large earthquakes (6 of the 29 earthquakes $\geq M_{\mathrm{w}} 8.1$ in the circum-Pacific since 1950 , Table 1) reinforce that it is frequently capable of generating tsunamigenic events. For these reasons, a $1000 \mathrm{~km}$ long rupture length and $200 \mathrm{~km}$ fault width is speculated herein as a potential worst-case scenario (Table 2), compatible with the subduction interface-zone parameters proposed by Berryman et al. (2015) for the Kuril-Kamchatka margin. According to the empirical relationship of Hanks and Kanamori (1979), such a rupture results in an $M_{\mathrm{W}}=9.28$ earthquake with $\sim 17 \mathrm{~m}$ slip.

Tsunamigenic-earthquake sources from the AleutianAlaska margin include earthquakes in 1957, 1964, and 1965 (e.g. Johnson and Satake, 1993; Johnson et al., 1994, 1996; Wesson et al., 2007). The $1957 M_{\mathrm{w}}=8.6$ Andreanof Islands earthquake had a very long rupture length of $850 \mathrm{~km}$ and $10 \mathrm{~m}$ of slip (Johnson et al., 1994). Although smaller in magnitude than the $1964 M_{\mathrm{w}}=9.2$ Prince William Sound and $1965 M_{\mathrm{w}}=8.7$ Rat Islands earthquakes, the 1957 event in the western Aleutian Arc generated a more destructive transPacific tsunami that caused significant damage in Hawaii, and was recorded in Chile, El Salvador, Japan, and the Marquesas Islands of French Polynesia (USGS database). The $1946 M_{\mathrm{w}}=8.1$ Unimak Island earthquake also generated a great trans-Pacific tsunami that caused extensive damage and loss of life in Hilo (Hawaii), and reached French Polynesia, Chile, and Antarctica. Fault-source parameters for this earlier event were poorly constrained by the data and technology available, and more recent studies have argued for various tsunami-generation mechanisms that incorporate a triggered large-submarine landslide along the continental slope (e.g. Fryer et al., 2004; Okal and Hébert, 2007). For this reason we closely follow the damaging 1957 event in the simulation herein because the source geometry and mechanisms are better constrained and less controversial. Such examples highlight the complexity of the tsunamigenic sources and our continually evolving - and retrospective - understanding of them.

For Cascadia, a worst-case scenario is developed as no recent reanalysis provides reliable fault parameters for a great earthquake. In general agreement with other regional data (Christensen and Beck, 1994; Johnson et al., 1996), a rupture length of $1050 \mathrm{~km}$ is assumed, which generates a tsunamigenic earthquake with a magnitude of $M_{\mathrm{w}}=9.1$ and $17.5 \mathrm{~m}$ of slip.

For great earthquake ruptures along the central Peru subduction zone, we are guided by the reanalysis by Beck and Nishenko (1990) of the 1868 Peru and 1906 ColombiaEcuador great earthquakes. Herein we simulate the $13 \mathrm{Au}-$ gust $1868 M_{\mathrm{w}}=9.0$ earthquake off Peru, using a rupture length of $900 \mathrm{~km}$ with $15 \mathrm{~m}$ of slip. Southern South America has a rich history of tsunamigenic earthquakes, including the largest earthquake recorded, the $1960 M_{\mathrm{w}}=9.5 \mathrm{Val}-$ divia event along the Chilean Trench (e.g. Kanamori, 1977), which generated a tsunami affecting the entire Pacific. Many interpretations of the fault parameters for the 1960 Chile earthquake have been proposed, but we follow the reanalysis, tsunami modelling, and ground truth testing by Heinrich et al. (1996). They argued that the best comparison between modelled waves and records along the Chilean coast and Tahiti was obtained from a fault-source solution proposed by Cifuentes (1989) using a fault area $920 \mathrm{~km}$ long and $120 \mathrm{~km}$ wide, a dip of $12^{\circ}$, and dislocation slip of $32 \mathrm{~m}$. The resulting moment magnitude calculated herein is $M_{\mathrm{w}}=9.29$, broadly compatible with the seismic moment of $M_{\mathrm{w}}=9.2$ recently reanalysed by Fujii and Satake (2013).

The regional earthquake sources are located in the South Vanuatu Trench, central Vanuatu back-arc, North Vanuatu Trench, and the Tonga Trench. The Tonga Trench in particular experiences recurrent great earthquakes that have generated damaging tsunamis (e.g. Beavan et al., 2010) and, therefore, represents a significant and credible hazard to the surrounding South Pacific region. For this reason five earthquake scenarios are developed for the Tonga Trench and 
three for the Vanuatu Trench region based on variations in the source parameters along the trench. Other seismically active regions are unlikely to generate tsunami as fault orientations are predominantly transcurrent, or are small normal faults associated with rifting (Pelletier et al., 1998). Local tsunami-generating mechanisms, such as landslides or volcanic eruptions, are not considered and fall outside the scope afforded by the current study.

In the Tonga Trench region, two historical great earthquakes had epicentres $\sim 110 \mathrm{~km}$ apart and generated damaging tsunami: 26 June $1917\left(M_{\mathrm{w}}=8.4\right)$ and 29 September $2009\left(M_{\mathrm{w}}=8.1\right)$ (Engdahl and Villasenor, 2002; Okal et al., 2010). A scenario is based on the latter 2009 rupture using source parameters determined by Beavan et al. (2010) and Lay et al. (2010), and is validated against post-tsunami observations in Samoa (Dominey-Howes et al., 2009) and further validated by Lamarche et al. (2015) against observations in Futuna-Alofi (Lamarche et al., 2010). A worst-case Tonga Trench scenario is developed using a long rupture length of $1000 \mathrm{~km}$ - the entire Tonga segment of the Pacific-Australia plate boundary - to generate an $M_{\mathrm{w}}=9.1$ earthquake with $20 \mathrm{~m}$ of slip (Table 2). This scenario is then made even more extreme by adding an arbitrary $+1 \mathrm{~m}$ water height at the time of the tsunami initiation to replicate a higher tide. A central Tonga scenario is similar to that of the $2009 M_{\mathrm{W}}=8.1$ event, but with an increased fault length of $600 \mathrm{~km}$. A north Tonga scenario is based on a $300 \mathrm{~km}$ long rupture along the North Fiji transform fault zone with $6 \mathrm{~m}$ of displacement, generating an $M_{\mathrm{w}}=8.16$ event (Table 2 ).

In the Vanuatu Trench region, a north Vanuatu Trench scenario uses a fault source located west of the Vanuatu Archipelago. Based on the Vanuatu trench morphology, Lamarche at al. (2015) estimated a rupture length of $400 \mathrm{~km}$, oriented NNW-SSW, with $10 \mathrm{~m}$ of displacement to generate an $M_{\mathrm{W}}=8.39$ event. A south Vanuatu scenario uses a fault source parallel with the south Vanuatu Trench, corresponding to the location of the 20 September $1920 M_{\mathrm{w}}=8$ earthquake that generated a tsunami in the Loyalty Islands (Sahal et al., 2010). Based on the Vanuatu Trench morphology Lamarche et al. (2015) estimated a $300 \mathrm{~km}$ long rupture with $8 \mathrm{~m}$ of displacement, resulting in an $M_{\mathrm{W}}=8.24$ event. The source parameters for the Vanuatu back-arc scenario are based on the $1999 M_{\mathrm{W}}=7.5$ Ambrym earthquake (Régnier et al., 2003) that generated a tsunami in Vanuatu (Pelletier et al., 2000). Using the tsunami numerical model of Ioualalen et al. (2006) for that event, Lamarche et al. (2015) applied a fault length of $200 \mathrm{~km}$, capable of generating an $M_{\mathrm{w}}=7.96$ earthquake and $6 \mathrm{~m}$ of seafloor displacement along the central Vanuatu back-arc thrust zone (Table 2).

\subsection{Tsunami model parameterization}

Tsunami modelling is achieved using Gerris Flow Solver (Popinet, 2003). The Saint-Venant (or non-linear shallow water) equations (de Saint-Venant, 1871) used for numerical tsunami simulations have been integrated into Gerris, with details of the solution method and application using Gerris summarized in Popinet (2011) and Popinet (2012), respectively. In the time-dependent tsunami simulations, the adaptive grid generated in Gerris refines and coarsens to select the appropriate grid resolution to capture the tsunami wave evolution. This approach of dynamically adaptive mesh refinement can lead to orders of magnitude gains in computational efficiency compared to non-adaptive methods, of particular relevance in far-field trans-Pacific multi-kilometrescale simulations requiring simultaneous resolution of metrescale inundation processes. The initial wave elevation is generated from a source model derived using seismic data only. The study by Popinet (2012) of the 2011 Tohoku earthquake compared the tsunami simulated using Gerris with observational records from DART buoys, GLOSS tide gauges, and fine-scale flooding using satellite and field data; the results demonstrated that Gerris provided an accurate prediction of the long-distance wave and yielded considerable confidence that, in partnership with an accurate source model, Gerris can be applied to trans-Pacific tsunami simulations.

When running the model, there is a balance between accuracy (grid resolution) around the islands, and the need to complete the runs in a timely fashion (weeks rather than months of computation). For the scenarios used herein, the regional simulations are run with spatial grid scales spanning $62500 \mathrm{~m}$ down to a minimum of $31 \mathrm{~m}$, while the distant simulations span grid scales of $208498 \mathrm{~m}$ down to a minimum of $25 \mathrm{~m}$. Here, the minimum grid size is limited by the resolution afforded by the elevation data for each of the atolls, which in most cases carries significant uncertainty. Additional high-resolution data of sufficient density and accuracy, such as remotely sensed laser-light elevations (lidar), would be required to generate meaningful results for grid sizes $<25 \mathrm{~m}$. As noted above, the current radar-derived vector data are not sufficient in this regard.

\section{Results from tsunami model simulations}

\subsection{Distant-earthquake sources}

The simulated maximum tsunami-wave amplitudes above sea level $\left(H_{\max }\right)$ are compiled for all distant sources, and the range of wave amplitudes is large $(0.125-7.9 \mathrm{~m})$ (Fig. 5). The largest earthquake sources can be seen from the elongated red streaks of high wave amplitudes around the Pacific basin. As the wave travels from the source region, it encounters topography in the form of sea floor bathymetry, seamounts, seamount chains, and other islands and larger landmasses, each of which can accelerate, slow, and scatter the incident wave field, transforming the original single coherent wave into a train of waves. The abrupt squared-off ends of some of the colour swathes mark the end of the model simulations: when these data indicate that the tsunami wave had long since 
Table 3. Arrival times in hours (h) and minutes ( $\mathrm{min}$ ) for waves from distant- and regional-earthquake simulations. The first occurrences of tsunami waves greater than $10 \mathrm{~cm}$ height are used to define initial arrival times at Tokelau and approximate tsunami event duration.

\begin{tabular}{llllll}
\hline Distant source & $\begin{array}{l}\text { Magnitude } \\
\left(M_{\mathrm{W}}\right)\end{array}$ & Atafu & Nukunonu & Fakaofo & $\begin{array}{c}\text { Approximate } \\
\text { duration }\end{array}$ \\
\hline Aleutian & 8.6 & $8 \mathrm{~h} 15 \mathrm{~min}$ & $8 \mathrm{~h} 25 \mathrm{~min}$ & $8 \mathrm{~h} 30 \mathrm{~min}$ & $\sim 2 \mathrm{~h}$ \\
Chile & 9.29 & $13 \mathrm{~h} 40 \mathrm{~min}$ & $13 \mathrm{~h} 30 \mathrm{~min}$ & $13 \mathrm{~h} 30 \mathrm{~min}$ & $>3 \mathrm{~h}$ \\
Kuril & 9.28 & $8 \mathrm{~h} 20 \mathrm{~min}$ & $8 \mathrm{~h} 25 \mathrm{~min}$ & $8 \mathrm{~h} 35 \mathrm{~min}$ & $>3 \mathrm{~h}$ \\
Peru & 9.0 & $15 \mathrm{~h} 15 \mathrm{~min}$ & $15 \mathrm{~h} 10 \mathrm{~min}$ & $15 \mathrm{~h} 00 \mathrm{~min}$ & $>2 \mathrm{~h}$ \\
Tohoku & 9.0 & $8 \mathrm{~h} 55 \mathrm{~min}$ & $8 \mathrm{~h} 55 \mathrm{~min}$ & $8 \mathrm{~h} 55 \mathrm{~min}$ & $>3 \mathrm{~h}$ \\
\hline Regional source & & & & \\
\hline Northern tip Tonga & 8.16 & $50 \mathrm{~min}$ & $50 \mathrm{~min}$ & $50 \mathrm{~min}$ & $>70 \mathrm{~min}$ \\
Tonga trench & 9.06 & $70 \mathrm{~min}$ & $65 \mathrm{~min}$ & $60 \mathrm{~min}$ & $>3 \mathrm{~h}$ \\
\hline
\end{tabular}

passed through Tokelau, there is minimal threat of significant wave reflections, and there is no additional benefit in continuing the simulations.

The Kuril earthquake source generates particularly high wave amplitudes that mask other sources in this type of summary schematic. For this reason, Fig. 6 replicates Fig. 5, except that the Kuril event is excluded from the compilation of maximum tsunami sources. In comparing the upper frames in Figs. 5 and 6 it is noticeable that the worst-case Kuril event generates a response at the Tokelau Islands substantially larger than that of all the other simulations. The tsunamiwave amplitude in the vicinity of the Islands is around $50 \mathrm{~cm}$ excluding the Kuril event, but the wave amplitude is potentially over $1 \mathrm{~m}$ with a Kuril event included. This is not simply a reflection of the relative initial earthquake magnitude of the Kuril event. Wave fields are channelled by the bathymetry of the Pacific basin in such a way that the largest wave amplitudes miss the Tokelau Islands. Similarly, for the $M_{\mathrm{w}}=9.1$ Cascadia event, the propagation is such that no significant wave amplitudes are registered at Tokelau. Importantly for hazard assessment, these simulations reinforce that earthquake event magnitude is not the only factor when determining the likelihood of significant waves at Tokelau. Here, the azimuth of the wave front and propagation direction across the seafloor are also significantly influential. The regional earthquake-source simulations show similar behaviour and interaction with the bathymetry.

Of the three atolls, the villages on Nukunonu and Fakaofo have more potential for inundation along their margins during the largest events because of their low and narrow land area. Our simulation suggests that the Tohoku event resulted in some modelled inundation, but much of the land surrounding the villages remained dry, notwithstanding the large uncertainties. Further validation of this modelled result could be yielded from observations after the Tohoku event in 2011 and Kuril earthquakes over recent decades, and incorporating these with information on the tidal state when the waves arrived. However, to the best of our knowledge there is no observational legacy of unusual tides or surges, or other phenomena that could be linked to such events.

Modelled run-up-height estimates for Tokelau are calculated using the maximum estimates from all distant-source simulations. Model outputs are simplified to highlight which parts of the atolls are most likely to remain dry under a series of plausible scenarios, with the villages being areas of greatest interest. The results of the tsunami simulations are portrayed as a colour ramp of the maximum inundation distance (horizontal) and flood depth (in centimetres) vertically above land, $H_{\text {in }}$. A static impression of the summary maximum wave amplitude (above a specified zero level of m.s.l. or MHWS) and inundation at Atafu can be obtained by integrating the full simulation time history into just a single image (Fig. 7). However, a particular challenge for our study is to ascertain enough topographic data to allow the model to adequately interpolate between the seaward and lagoon sides of each atoll. For the distant-earthquake simulations, tsunami arrival times are in excess of $8 \mathrm{~h}$ for sources in the western part of the Pacific basin, and in excess of $13 \mathrm{~h}$ for Chile and Peru sources in the eastern part of the Pacific (Table 3). Hence, warning times are relatively long.

Our simulations reinforce that each tsunami event is generally not characterized by the rapid passage of a simple, single wave front before returning to rest. Events could persist for $2-3 \mathrm{~h}$, during which time the wave field may remain at levels capable of generating potential inundation (Table 3). The wave train may persist across the Pacific for days, but model simulations were stopped when the threat for further significant flooding was considered low.

\subsection{Regional-earthquake sources}

Seven regional scenarios are modelled, but only two (northern tip Tonga and Tonga Trench) resulted in wave amplitudes over $10 \mathrm{~cm}$ at the Tokelau Islands and $H_{\max }$ is typically less than $30 \mathrm{~cm}$ (Fig. 8). The regional sources used in this study are generally located to the south or southwest of the Tokelau Islands and, when combined with the fault orientation 


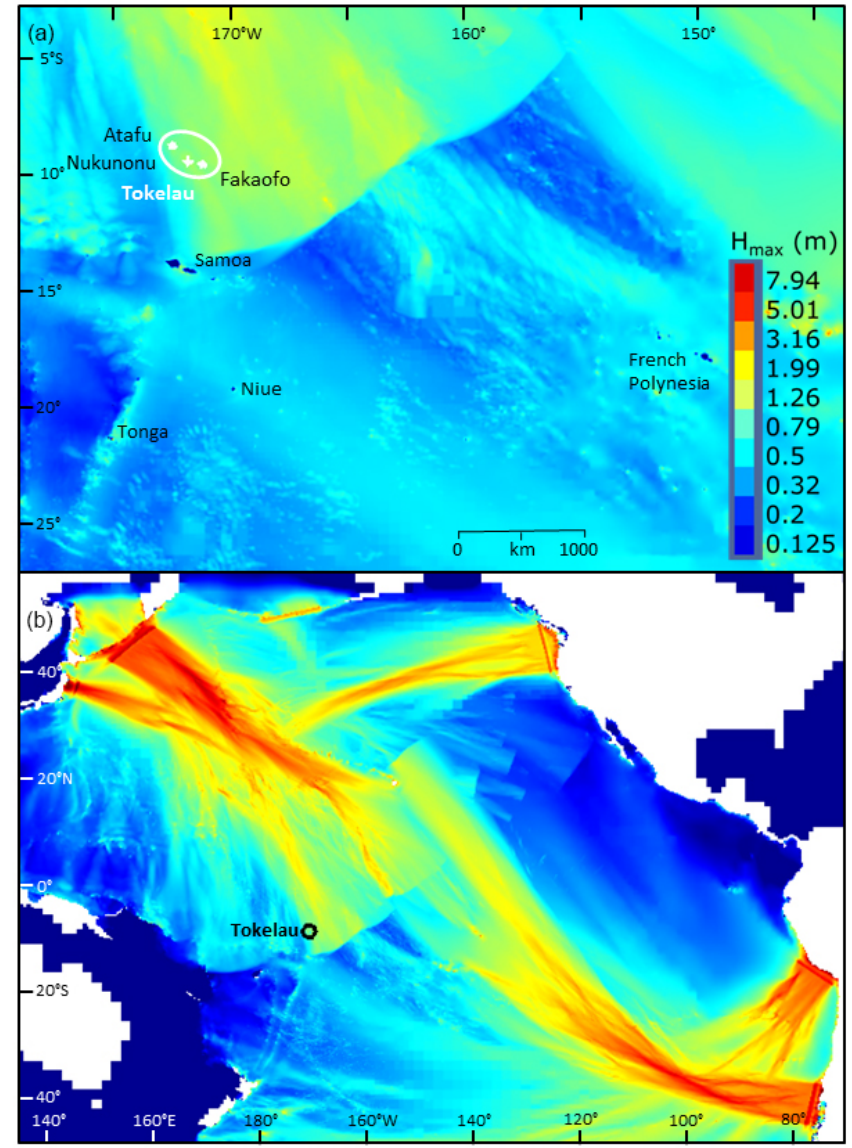

Figure 5. Summary of maximum wave amplitudes for all distant sources. The top frame (a) provides a regional focus of the southwestern equatorial Pacific, with the Tokelau Islands outlined in white. The lower frame (b) provides a wider view of the Pacific Ocean and the distant, trans-Pacific tsunami source regions, with the Tokelau Islands outlined in black. Note that simulations stop after the majority of the tsunami-wave train has passed Tokelau, giving a truncated appearance to farthest extents of the wave fields. The height is plotted on a logarithmic scale (same for both images) to adequately capture the wide range of wave amplitudes in both frames $(0.125 \mathrm{~m}$ in dark blue to over $7.9 \mathrm{~m}$ in red).

and bathymetry in this region, the simulations suggest that the Tokelau Islands are relatively sheltered (particularly by the Samoa Islands chain) such that wave amplitudes exceeding $0.5 \mathrm{~m}$ are predicted to occur further west and east of the Tokelau Islands, but do not impact Tokelau.

Simulations of maximum tsunami inundation depth show some inundation on each of the islands resulting from the maximum regional source simulations, but significant areas of land remain dry (Fig. 9). The amplitudes and patterns of inundation are comparable to the distant events excluding Kuril (Fig. 6), and reflect the influence of each island's topography. Hence, the simulated land areas identified as dry for the distant earthquake sources are also predicted to stay dry for regional sources.

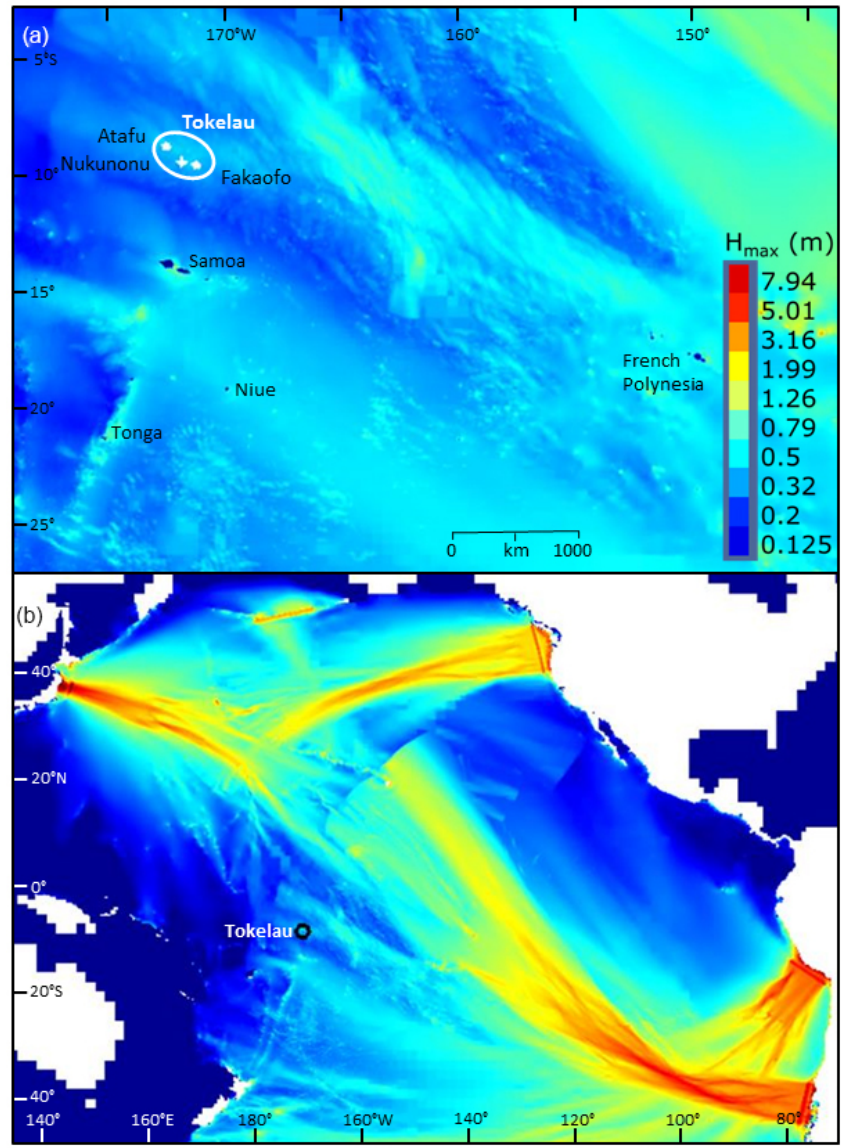

Figure 6. Summary of maximum wave amplitudes for all distant sources excluding Kuril. The regional view (a), with the Tokelau Islands outlined in white, upper left. And a wider view of the Pacific Ocean (b), with the location of Tokelau indicated by the black circle. Note that simulations stop after the majority of the tsunamiwave train has passed Tokelau, giving a truncated appearance to farthest extents of the wave fields. The height is plotted on a logarithmic scale (same for both images) to adequately capture the wide range of wave amplitudes in both frames $(0.125 \mathrm{~m}$ in dark blue to over $7.9 \mathrm{~m}$ in red).

The significant point of difference for the regional- versus the distant-earthquake source simulations is the arrival times of the first significant tsunami waves, a function of travel distance. Arrival times of $50 \mathrm{~min}$ (northern tip Tonga) to around 65 min (Tonga Trench) are to be expected, with event durations of 1-3 h (Table 3); therefore lead times for implementing any emergency plan will be short for such regionally generated events.

\subsection{Summary of results from simulations}

From the 14 potential distant and regional tsunami sources investigated in this hazard appraisal, nearly all have land areas within the villages of the Tokelau Islands that will remain dry. The scenarios sample a range of earthquake sources in 

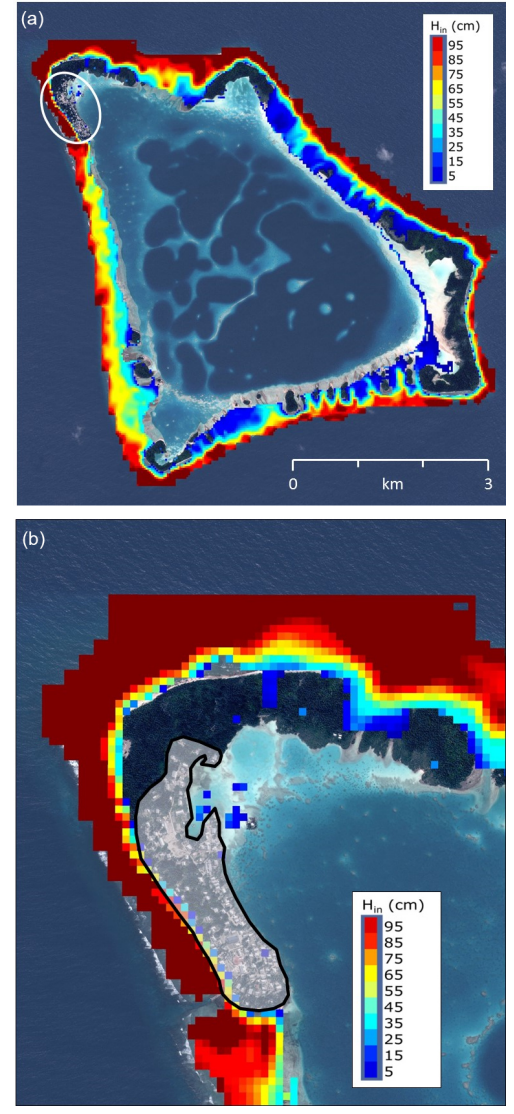

Figure 7. (a) Modelled maximum inundation for the atoll Atafu using the maximum estimates from all distant-earthquake source simulations. (b) Zoomed in image of the modelled tsunami-flood inundation depths (above m.s.l.) for the village on Atafu in the northwestern corner of the atoll (indicated by the semi-transparent grey area) from all distant-earthquake sources. For both images, the colour bar legend shows the maximum tsunami-flood inundation depth (in centimetres above land, $H_{\text {in }}$ ). The uncoloured areas, where the underlying satellite image of the atoll and islets can be seen, are emergent land areas that remain dry during the modelled tsunami flooding events. The area of the village is circled in white (a) and outlined by the semi-transparent grey area (b). The lagoon and fringing reef are not considered land in the model so have no colour, but because these areas are so shallow, on occasion one or two grid squares of colour might occur away from the known areas of land.

terms of magnitude, orientation, and distance from the Tokelau Islands. Given that there have been eight tsunamigenic earthquakes $\geq M_{\mathrm{w}} 8.1$ since the year 2000, two of which are among the largest recorded earthquakes in the world since 1900 , it is reasonable to assume that tsunami hazards are small to moderate. Collectively, the outcome that none of the modelled tsunami waves overwash any of the atolls is broadly consistent with living memory of the islanders and oral history of little or no perceived threat of tsunami.

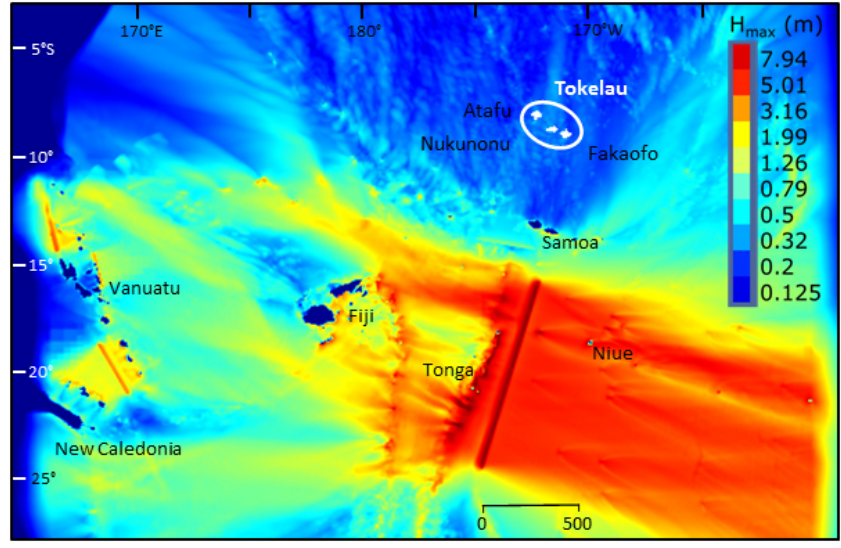

Figure 8. Maximum wave amplitudes (above m.s.1.) for the compilation of maximum regional source simulations (the colour scale for $H_{\max }$ shows $0.125 \mathrm{~m}$ in dark blue to $7+\mathrm{m}$ in red). The atolls of Tokelau are indicated in white and circled (upper right).

The static images used in this report represent a snapshot of a tsunami-event scenario as the tsunami wave interacts with each of the atolls. However, other wave behaviour is evident when the complete wave passage is viewed as a movie, emphasizing wave dynamics and refraction effects around the atolls, islets, tidal channels, and within the lagoons. Deep channels through the fringing-reef matrix in particular can allow for the propagation of far more tsunami energy than shoals protected by reefs or islets (cf. Gelfenbaum et al., 2011). The simulations run at MHWS reinforce that during the largest events, run-up is also possible from the lagoon side of the atoll, as the reef flat does not provide a barrier to wave propagation.

\section{Discussion}

\subsection{Comparison to other tsunami simulations for Pacific Ocean atolls}

Central Pacific Islands are essentially surrounded by seismogenic subduction zones that are a defining geological feature of the Pacific Rim. However, despite the large number of these tsunamigenic sources, previous simulation studies have suggested that the occurrence and behaviour of potentially dangerous trans-Pacific tsunami in the South Pacific is moderated by a combination of the fault-strike angle, arrival azimuth, and deep-ocean bathymetry (e.g. Hébert et al., 2001a, b). Linear seafloor features, such as the large Hawaiian Ridge and East Pacific Rise, can trap, scatter, or redirect wave energy from tsunami sources. Results from our simulations agree with these prior studies and suggest that the deep surrounds of the Tokelau atolls reduce the tsunamiwave amplitude amplification in the region in general. The swathe of maximum wave amplitudes from the Kuril simulation - the seismogenic source in our simulations that re- 

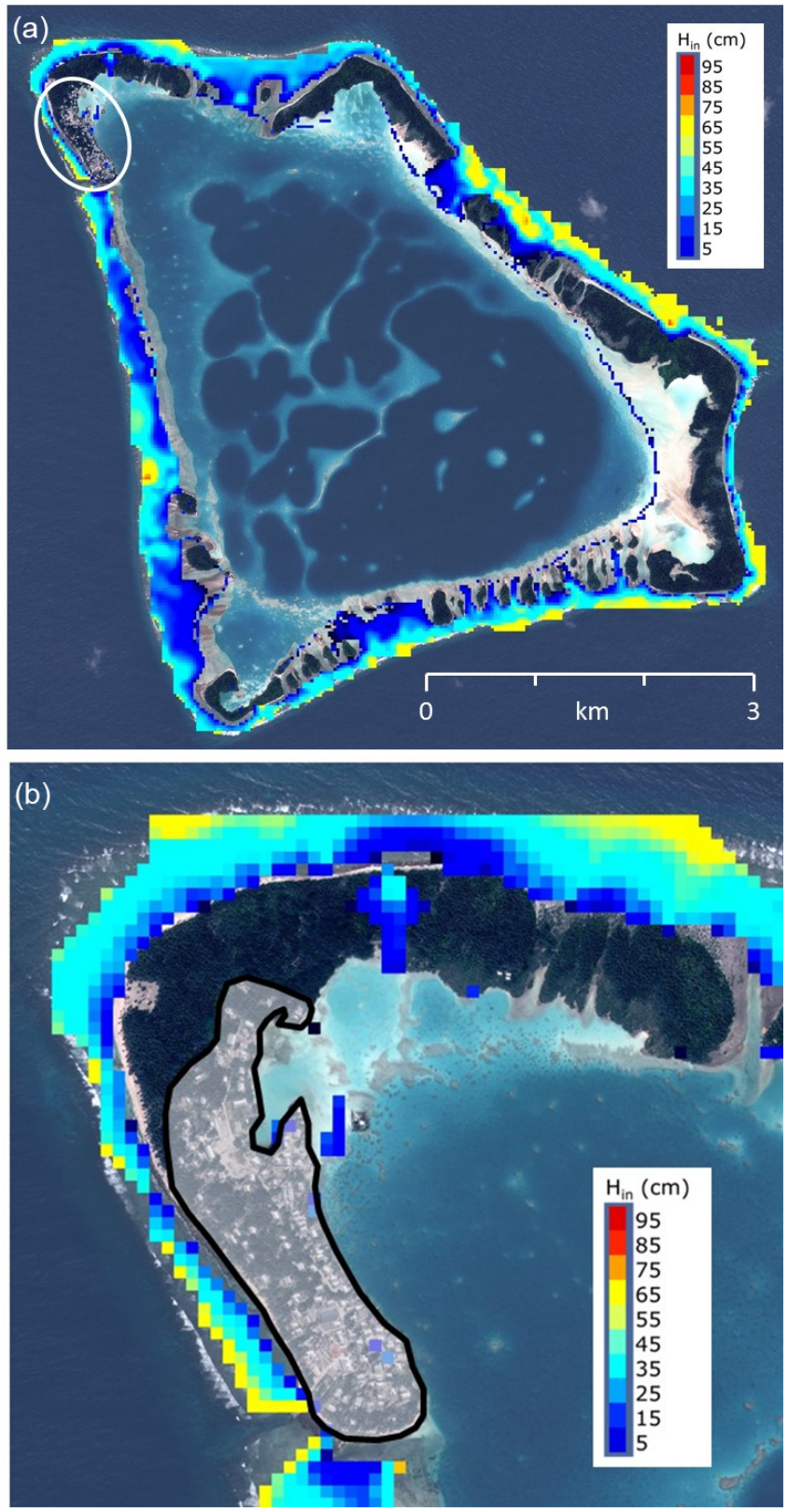

Figure 9. (a) Modelled tsunami-flood inundation depths (in centimetres above land, $H_{\text {in }}$ ) on the atoll of Atafu from all regionalearthquake sources. The location of the village is outlined by the white ellipse. (b) Zoomed in image of the modelled tsunamiflood inundation depths for the village on Atafu from all regionalearthquake sources. The land area of the village is indicated by the semi-transparent grey area.

sults in the strongest tsunami wave at Tokelau - passes immediately northeast of Tokelau, with amplification $\sim 50 \mathrm{~cm}$ greater than that of waters around Tokelau (Fig. 5).

Peculiar to atolls as emergent features that can be impacted by tsunami, results from a previous study for the Tuamotu Archipelago of French Polynesia by Sladen et al. (2007) sug- gest that observational run-up data from moderate tsunamis are consistent with offshore wave amplification, inferring that only moderate tsunami hazards might exist on reeffringed atolls. They suggest that this behaviour is caused, in part, by the long wavelength relative to the short length of the steep bathymetric slope, and energy dissipation from wave reflection and breaking along the atoll crest. Our results are broadly consistent with these findings as none of the worstcase scenarios resulted in complete inundation of the Tokelau village islets; but simulated wave amplitudes can exceed the tidal range nonetheless. As noted by Sladen et al. (2007), gaps in the reef may behave differently and present greater hazards with respect to elevated run-up heights. Results from our simulations run at MHWS show elevated heights through tidal channels and within the lagoon (as discussed below). Given that atolls have such low relief, there is little room for complacency, as evidenced by wave amplitudes $>2 \mathrm{~m}$ from the 2004 Sumatra tsunami at the Maldives (Rabinovich and Thomson, 2007) and the accompanying destruction recorded on the Marshall Islands in the aftermath of the 2011 Tohoku tsunami (Ford et al., 2014).

With respect to impacts of tsunami in the wider equatorial Pacific from great earthquakes, following the $M_{\mathrm{w}}=9.0 \mathrm{To}-$ hoku earthquake and tsunami in 2011, Ford et al. (2014) suggest that the impacts on Pacific Ocean atolls were relatively minor. Indeed, they report that since 1946, of the 26 tsunami events recorded at Kwajalein Atoll in the Marshall Islands, the highest water level measured on a tidal gauge was only $0.38 \mathrm{~m}$.

\subsection{Behavioural characteristics of tsunami interactions within the atolls of Tokelau}

The Gerris simulations generated significant wave amplitudes within the atolls themselves, which can be captured with the fine, adaptive local grid resolution around each atoll. Snapshots using the Kuril-source experiment at MHWS demonstrate some of the behavioural characteristics of waves within the lagoons, taken using successive $100 \mathrm{~s}$ increments from $\sim 1 \mathrm{~h}$ after the arrival of the first wave train at Atafu (Fig. 10). A range of solutions are obtained within the lagoons as the oceanic wave progresses from northwest to southeast through the Tokelau group. Here, the minimum spatial resolution of the simulation is adapted to $25 \mathrm{~m}$ relative to typical atoll scales of 5-10 km across, with resulting wave amplitudes from 0.5 to $1.5 \mathrm{~m}$. Given the grid resolution and other uncertainties (e.g. lagoon bathymetry), the general wave behaviours revealed in the simulations can be considered illustrative rather than quantifiable per se.

For Atafu, a wave initially crosses the western reef (Fig. 10d), and then propagates eastward across the lagoon (Fig. 10e and f). There are also wave intrusions through the reef matrix on the northern and southern sides of the atoll, which interfere with the traverse of the larger wave across the lagoon. Close inspection of these frames also reveals that the 
dry atoll regions (in black) change in size as the waves inundate and recede. For Nukunonu (Fig. 10g-i), a wave overtops the northern reef, and then propagates southward across the lagoon, with another wave impinging from the north; these frames also show a series of waves generated by previous incursions into the lagoon propagating and interacting with each other. For Fakaofo (Fig. 10j-1), numerous waves interact, produced by flow through Fakaofo's relatively complex fringing reef and islets, giving a more circular character to the wave fronts. Examination of the successive time increments (Fig. 10j-1) reveals a series of wave fronts that travel northwards and then to the northeast, eventually filling the entire lagoon.

Close inspection of the complex wave patterns within each atoll reveals changes in the area of dry land as the lagoon waves surge and recede. Upon arrival of the wave front, each atoll is simultaneously responding differently, which may be important for any civil advisory for individual atolls. This aspect of the depiction might be lost if the wave fronts were matched by phase rather than time. Together with wave amplitudes within the atolls that exceed $50 \mathrm{~cm}$, there will likely be increased inundation on sections of the lagoon shorelines. It is also apparent that the propagation timescale for the lagoon waves differs from that of the oceanic wave outside the atoll, raising potential for phase effects if the oceanicwave set-up interferes with the arrival of a wave from within the lagoon. As such, these complex wave fields and interactions may also influence evacuation strategies for the individual villages between atolls. Furthermore, such strategies will likely differ from typical coastal-island settings where retreat from the open ocean might be considered a safe option.

Here, Gerris solves the Saint-Venant equations (non-linear shallow water system), so will not reproduce the required dispersion relations as the topography shoals around the atolls. This dispersion is more correctly addressed using the so-called Boussinesq-Green-Naghdi variants of the shallow water systems (e.g. Panda et al., 2014, and references therein), and such equations can be solved using a new adaptive system called Basilisk (e.g., Popinet, 2014, 2015; Beetham et al., 2016).

\subsection{Tsunami evacuation advisory: identifying key information relevant to end-users}

In order to provide some kind of summary advisory for emergency planning for the Tokelau Islands in the event of a major tsunami, the combined maximum tsunami-flooding results from the numerical modelling have been used to inform evacuation strategies. Scenarios that are not hazardous or potentially hazardous or worst case are of lower relevance to a civil advisory as they are likely to be a lesser threat. The results are presented in terms of the tsunami-wave run-up height, the maximum elevation on land to which the sea inundates above the initial sea level as a result of the tsunami event. Given the uncertainty of the topography used in this study, referencing the run-up height back to sea level is considered more meaningful and potentially provides a more tangible and less ambiguous point of reference for the islanders. For each island the highest run-up from three cases is recorded. Two cases are based on the largest distant sources: one with, and one without the Kuril-source simulation. A third case records the highest run-up simulated from the combined maximum regional sources.

Results from the current study and those from some other tsunami simulation studies for the south-central Pacific (e.g. Hébert et al., 2001a) emphasize the importance of wave orientation from specific tsunamigenic sources when considering inundation hazard for a particular location. To better recognize wave orientation as part of an advisory, for each of the semi-circular atolls, compass quadrants are used to provide a geographically practical means to assess the impact of the tsunami simulations on specific sections of the atoll and the main village(s) (Table 4). For each geographic region, the maximum run-up height (in metres) is given above the specified local sea level: mean sea level (m.s.l.) and estimated Mean High Water Spring (MHWS). The construction of our civil advisory captured in Table 4 is, necessarily, simplistic and considers only five essential variables: (i) a great earthquake from Kuril; (ii) another significant distant great earthquake; (iii) a significant regional source; (iv) the effect of tidal height; and (v) quadrant of the island. In short, the underlying questions are as follows: which quadrants of the atolls remain dry, and which earthquake sources present the greatest threat to that quadrant?

In some cases, run-up heights for simulations with sea level at MHWS are lower than the equivalent earthquake sources run at m.s.l. This may seem counterintuitive and the reverse of what might be expected. An explanation for this behaviour may come from a simulation study by Gelfenbaum et al. (2011) that explored the effect of fringing reefs on tsunami inundation in American Samoa. Their study suggested that when fringing reefs are narrow $(<200 \mathrm{~m}$ wide), greater wave amplitudes onshore are encouraged by shoaling interaction with the fringing reef. However, as the reef width increases ( $\gg 200 \mathrm{~m}$ ), dissipation of wave energy from bottom friction begins to dominate over shoaling and causes the tsunami-wave amplitudes to decrease. The fringing reefs around the atolls of Tokelau range in width from $\sim 75$ to $400+\mathrm{m}$, but are variable laterally depending on the relative position of emergent islets. Whether the Tokelau reef flats are relatively wide when covered by the tide (MHWS), or exposed (m.s.l.) at the time of arrival spans the transition between shoaling or bottom-friction dominant wave behaviour.

For the geographic regions of each atoll, an area of dry land is considered "SAFE" if it is (a) above the maximum inundation height, and (b) of substantial size. Given the relative uncertainties of the true atoll topography, our advisory is therefore conservative. Elevations considered to be the minimum SAFE evacuation height in the event of a major tsunami are compiled in Table 4. In some regions the result is flagged 

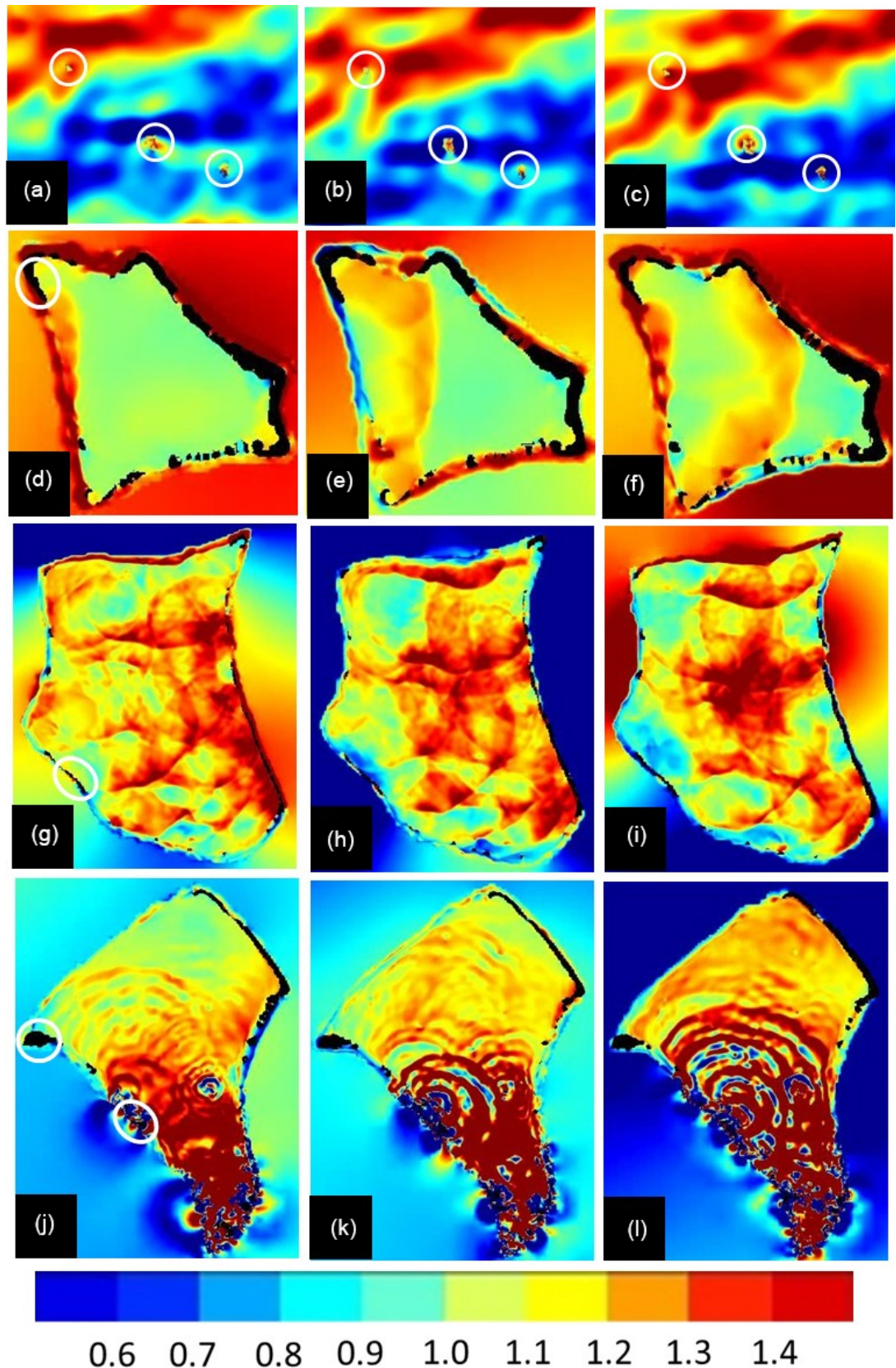

Figure 10. Illustrative snapshots of wave fields within atolls generated from the Kuril-source MHWS simulation. Columns show water heights (relative to initial value at MHWS) for successive $100 \mathrm{~s}$ increments progressing from left to right in all three columns, the left-hand column at $1 \mathrm{~h}$ after the first wave-train arrival at Atafu. The top row (a-c) shows the oceanic wave field, the location of the three atolls within the white circles (Atafu, Nukunonu, and Fakaofo from left to right). The second row of frames (d-f) focuses on Atafu and follows the same time sequence as the top row, and similarly for Nukunonu $(\mathbf{g}-\mathbf{i})$, and Fakaofo $(\mathbf{j}-\mathbf{l})$. The colour scale bar along the base of the columns indicates the range of water heights from 0.5 to $1.5 \mathrm{~m}$.

as "NOT SAFE"; these are regions that are particularly lowlying, or where the estimated tsunami inundation is large. In such cases, the advisory defaults to a precautionary approach, in which the area should be completely evacuated. As the villages of the Tokelau Islands are located on the western sec- tors of the atolls, hazards to infrastructure will also be sensitive to tsunami source and wave orientation.

The particular distant earthquake-source simulations responsible for the maximum tsunami run-up are also identified in Table 4, and annotated accordingly as Chile (C), Kuril (K), Peru (P), and Tohoku (T). These tabulated results 
Table 4. Recommended minimum evacuation heights above local sea level (metres) for combined distant sources. To better recognize wave orientation as part of an advisory, four geographic quadrants for each atolls are considered: north (N), south (S), east (E), and west (W). Due to the shape of Fakaofo the northeastern (NE) and northwestern (NW) quadrants of emergent land are noted. Labels refer to the distant sources of Chile (C), Kuril (K), Peru (P), and Tohoku (T), as the earthquake source region that yielded the maximum run-up height from the series of tsunami simulations.

\begin{tabular}{|c|c|c|c|c|c|c|}
\hline Atafu (sea level at m.s.l.) & \multicolumn{2}{|c|}{ Main village (m) } & $\mathrm{N}(\mathrm{m})$ & $\mathrm{S}(\mathrm{m})$ & $\mathrm{E}(\mathrm{m})$ & $\mathrm{W}(\mathrm{m})$ \\
\hline Source including Kuril & \multicolumn{2}{|c|}{$2.5(\mathrm{~K})$} & $2.6(\mathrm{~K})$ & $1.8(\mathrm{~K})$ & $2.3(\mathrm{~K})$ & $1.5(\mathrm{~K})$ \\
\hline Distant source excluding Kuril & \multicolumn{2}{|c|}{$2.0(\mathrm{C})$} & $1.1(\mathrm{C})$ & $1.5(\mathrm{C})$ & $2.3(\mathrm{C})$ & $1.3(\mathrm{C})$ \\
\hline Regional sources & \multicolumn{2}{|l|}{1.5} & 0.7 & 2.0 & 1.3 & 0.8 \\
\hline \multicolumn{7}{|l|}{ Atafu (sea level at MHWS) } \\
\hline Source including Kuril & \multicolumn{2}{|l|}{$2.5(\mathrm{~K})$} & NOT SAFE & $1.8(\mathrm{~K})$ & $2.3(\mathrm{~K})$ & NOT SAFE \\
\hline Distant source excluding Kuril & \multicolumn{2}{|c|}{$1.6(\mathrm{~T})$} & $1.2(\mathrm{P})$ & $1.5(\mathrm{P})$ & $1.2(\mathrm{P})$ & NOT SAFE \\
\hline Regional sources & \multicolumn{2}{|l|}{1.6} & 1.0 & 1.1 & 1.2 & NOT SAFE \\
\hline \multicolumn{7}{|l|}{ Nukunonu (sea level at m.s.l.) } \\
\hline Distant source including Kuril & \multicolumn{2}{|c|}{$1.8(\mathrm{~K})$} & $2.0(\mathrm{~K})$ & $1.5(\mathrm{C})$ & $2.8(\mathrm{C})$ & $2.0(\mathrm{~K})$ \\
\hline Distant source excluding Kuril & \multicolumn{2}{|c|}{$1.8(\mathrm{C})$} & $1.2(\mathrm{C})$ & $1.5(\mathrm{C})$ & $2.8(\mathrm{C})$ & $1.0(\mathrm{C})$ \\
\hline Regional sources & \multicolumn{2}{|l|}{2.0} & 0.7 & 1.3 & 1.5 & 1.5 \\
\hline \multicolumn{7}{|l|}{ Nukunonu (sea level at MHWS) } \\
\hline Distant source including Kuril & \multirow{3}{*}{\multicolumn{2}{|c|}{$\begin{array}{c}\text { NOT SAFE } \\
1.4(\mathrm{C}, \mathrm{P}) \\
\text { NOT SAFE }\end{array}$}} & $1.8(\mathrm{~K})$ & NOT SAFE & $1.4(\mathrm{C}, \mathrm{K})$ & NOT SAFE \\
\hline Distant source excluding Kuril & & & $1.1(\mathrm{P})$ & NOT SAFE & $1.4(\mathrm{C})$ & $1.0(\mathrm{C})$ \\
\hline Regional sources & & & 1.1 & NOT SAFE & 1.1 & 1.5 \\
\hline Fakaofo (sea level at m.s.1.) & Main village (m) & Fale (m) & $\mathrm{NE}(\mathrm{m})$ & $\mathrm{S}(\mathrm{m})$ & $\mathrm{E}(\mathrm{m})$ & $\mathrm{NW}(\mathrm{m})$ \\
\hline Distant source including Kuril & $2.9(\mathrm{~K})$ & $1.7(\mathrm{P})$ & $2.3(\mathrm{C})$ & NOT SAFE & $1.6(\mathrm{C})$ & NOT SAFE \\
\hline Distant source excluding Kuril & $2.2(\mathrm{C})$ & $1.7(\mathrm{P})$ & $2.3(\mathrm{C})$ & NOT SAFE & $1.6(\mathrm{C})$ & NOT SAFE \\
\hline Regional sources & 1.5 & 1.3 & 0.8 & 1.8 & 1.1 & NOT SAFE \\
\hline Fakaofo (sea level at MHWS) & & & & & & \\
\hline Distant source including Kuril & $2.4(\mathrm{P})$ & $2.0(\mathrm{P})$ & $1.7(\mathrm{P})$ & NOT SAFE & NOT SAFE & NOT SAFE \\
\hline Distant source excluding Kuril & $2.4(\mathrm{P})$ & $2.0(\mathrm{P})$ & $1.7(\mathrm{P})$ & NOT SAFE & NOT SAFE & NOT SAFE \\
\hline Regional sources & 1.5 & 1.6 & 1.0 & 0.9 & NOT SAFE & NOT SAFE \\
\hline
\end{tabular}

highlight that the largest magnitude earthquakes are not always responsible for the highest predicted run-up around the atoll. The azimuth of the tsunami-wave arrival is critical to the run-up height. Furthermore, while trans-Pacific tsunami from Kuril might result in the maximum predicted inundation for the atoll in general, other earthquake sources may present greater threats for some quadrants of the atolls. Importantly, regardless of the earthquake source, the simulations predict that some areas of dry land would be preserved. The Tohoku tsunami is a recent event of historic significance that was recorded around the Pacific (e.g. Popinet, 2012; Ford, 2014). All the simulations imply some quantifiable run-up (i.e. something that could otherwise have been measured by a tide gauge, had one been installed) resulting from the Tohoku tsunami, but on a much smaller scale than that predicted for our Chile or Peru worst-case event, and significantly smaller compared to the Kuril event. The fact that there is no oral record of this tsunami by the Tokelauans might suggest that any increase in water height or behaviour was only minor and within the normal tidal range $(0.7 \mathrm{~m})$, consistent with the general findings of Ford et al. (2014) of relatively minor impacts in the Pacific Islands following the Tokoku tsunami.

In contrast, regional-earthquake sources generally result in lower tsunami run-up compared to distant sources, but southern sectors of the atolls are potentially less safe because regionally sourced tsunami waves typically arrive from southern latitudes.

For Atafu at MHWS, the trans-Pacific tsunami simulations predict a higher initial water level that covers most of the western geographical quadrant of the atoll and is deemed to be unsafe (Table 4). With the Kuril event specifically, there are still safe areas around the main village, and to the south and the east. But compared to the simulation with sea level at m.s.l., the northern quadrant is not considered safe. Excluding a Kuril source, the predicted run-ups are lower, and all areas might be regarded as potentially safe zones for evacuation except the western quadrant. The results for Nukunonu show that Kuril and Chile earthquake sources dominate the 
maximum run-ups. Again, for the simulation with sea level at m.s.1., safe evacuation heights for these sources can be found in each geographic quadrant of the atoll. In comparison to Atafu, for the simulation with the sea level at MHWS, the relatively low terrain of Nukunonu enhances reef passages between the open ocean and the lagoon. The result is that many geographical regions of Nukunonu are typically not safe and the main village itself is potentially liable to be completely inundated from a Kuril or regionally sourced earthquake (Table 4). For the distant sources not including Kuril (but including the 2011 Tohoku event), the main village remains largely dry, consistent with observations. Like Nukunonu, Fakaofo is relatively low-lying, with many areas open to the ocean at the highest tides. For all simulations, the southern and northwestern quadrants are typically not safe, as is the eastern quadrant for simulations at MHWS (Table 4). However, importantly, for all simulations, including a worst-case Kuril source that predicted the maximum inundation, the main villages on Fakaofo are expected to retain safe dry areas.

Flow depths and velocities would be worthy additions to a future study that had the additional advantage of incorporating (yet to be acquired) high-resolution topographic and bathymetric data. We note that the impacts for Tokelau using the flow depths outlined by Tinti et al. (2011, see Fig. 17 and Table 6 therein) would likely be no flooding (and no damage) or only slight flooding, as the villages are not inundated in our scenarios. Hence, the addition of flow-related model outputs could be premature and unwarranted at this stage. However, should an analysis of selected sea walls and gabions of Tokelau - primarily erected to mitigate the regular threat of storm surges - be considered to assess their long-term engineering integrity, tsunami flow velocities might add usefully to a more holistic analysis. For this to proceed, new and more accurate topographic maps are needed.

Studies such as this can provide additional confidence to islanders and inform community evacuation strategies. In addition, the current study shows that provisional, but informative, simulation studies can be achieved even with only basic field data, due in part to the relative simplicity of the atoll topography and the ability to glean elevation information from readily available data such as aerial photographs, selected beach profiles, and only partial multibeam coverage. In this case at least, the conical bathymetric form and low-relief characteristic of atolls is initially advantageous from a modelling perspective. However, unquestionably, better bathymetric and topographic data should encourage future studies and quantification of other hydrodynamic nuances peculiar to tsunami interactions with atolls.

\section{Conclusions}

A limited suite of historical and plausible earthquake scenarios is simulated with the adaptive numerical model Gerris Flow Solver to explore the potential tsunami hazard for the three atolls of the Tokelau Islands and earthquake sources that present the greatest potential to trigger an emergency response. This approach yields instructive results to inform a community advisory but is not intended to be fully deterministic. The immediate surrounds of all the villages essentially remain dry in our tsunami simulations, with a tsunami-wave event that may last a few hours and include several wave trains. Our series of 14 simulations infers that great earthquakes and trans-Pacific tsunami from distant sources pose the most significant inundation threat to the Tokelau Islands in general, and from the Kuril Trench and northern sources in particular. Consistent with other studies, our simulations show that tsunami-wave orientation impacts inundation at specific locations aligned to the wave front, particularly from distant-eastern sources from the Chile and Peru subduction margins, and regional-earthquake sources to the south. The lagoon and deep passages through the fringing-reef matrix can also propagate significant tsunami-wave energy, particularly if tides are high. Simulations suggest that complex wave fields and interactions may also occur within the lagoons, the heights of which could influence evacuation strategies for villages and differs from typical coastal-island settings. Our study shows that indicative simulation studies can be achieved even with only basic field information. In part, this is due to the spatially and vertically limited topography of the atoll, short reef flat and steep seaward bathymetry, and the simple depth profile of the lagoon bathymetry.

Acknowledgements. This tsunami hazard assessment was originally commissioned by the government of Tokelau in collaboration with the New Zealand government's Ministry for Civil Defence and Emergency Management (MCDEM). NIWA acknowledges their support for this study. The Geospatial Intelligence Organisation of the New Zealand Defence Force, and the New Zealand Hydrographic Authority of Land Information New Zealand kindly provided some bathymetric and topographic data. The authors offer special thanks to Stéphane Popinet for his ongoing development of Gerris Flow Solver and insights into the modelling challenges. Thanks also to Emily Lane for her constructive internal review, and Barb Hayden and Doug Ramsey for their backing. This study was supported by the Marine Physical Resources Programme within NIWA's Coasts and Ocean Centre, and the Pacific Rim Centre. Two anonymous referees and the guest editor are thanked for their constructive comments and patience.

Edited by: H. Hebert

Reviewed by: two anonymous referees

\section{References}

Beavan, J., Wang, X., Holden, C., Wilson, K., Power, W., Prasetya, G., Bevis, M., and Kautoke, R.: Near-simultaneous great earthquakes at Tongan megathrust and outer rise in September 2009, Nature, 466, 959-963, 2010. 
Beck, S. L. and Nishenko, S. P.: Variations in the mode of great earthquake rupture along the Central Peru Subduction Zone, Geophys. Res. Lett., 17, 1969-1972, 1990.

Beetham, E., Kench, P. S., O'Callaghan, J., and Popinet, S.: Wave transformation and shoreline water level on Funafuti Atoll, Tuvalu, J. Geophys. Res.-Oceans, 121, 311-326, doi:10.1002/2015JC011246, 2016.

Ben-Menahem, A. and Toksöz, M. N.: Source mechanism from spectrums of long-period surface waves: 2, The Kamchatka earthquake of November 4, 1952, J. Geophys. Res., 68, 52075222, 1963.

Berryman, K., Wallace, L., Hayes, G., Bird, P., Wang, K., Basili, R., Lay, T., Pagani, M., Stein, R., Sagiya, T., Rubin, C., Barreintos, S., Kreemer, C., Litchfield, N., Stirling, M., Gledhill, K., Haller, K., and Costa, C.: The GEM Faulted Earth Subduction Interface Characterisation Project, Version 2.0, April 2015, available at: http://www.nexus.globalquakemodel.org/gem-faulted-earth/ posts (last acces:s 23 May 2016), GEM Faulted Earth Project, 56 pp., 2015.

Christensen, D. H. and Beck, S. L.: The rupture process and tectonic implications of the great 1964 Prince-William-Sound earthquake, PA-GEOPH, 142, 29-53, 1994.

de Saint-Venant, A. B.: Théorie du movement non-permanent des eaux, avec application aux crues des rivières et á l'introduction des marées dans leur lit, Comptes Rendus des séances de l'Académie des Sciences, Paris, 73, 147-154, 1871.

Dominey-Howes, D., Thaman, R., and Goff, J.: UNESCO-IOC International Tsunami Survey Team Samoa (ITST Samoa), Interim Report of Field Survey 14th-21st October 2009, University of New SouthWales, Sydney 2052, NSW, Australia, 190 pp., 2009.

Engdahl, E. R. and Villasenor, A.: Global Seismicity: 1900-1999, Int. Handbook Earthq. Eng. Seismol., 81A, 665-690, 2002.

Ford, M., Becker, J. M., Merrifield, M. A., and Song, Y. T.: Marshall Islands fringing reef and atoll lagoon observations of the Tohoku tsunami, Pure Appl. Geophys., 171, 3351-3363, doi:10.1007/s00024-013-0757-8, 2014.

Fryer, G. J., Watts, P. and Pratson, L. F.: Source of the great tsunami of 1 April 1946: a landslide in the upper Aleutian forearc, Mar. Geol., 203, 201-218, 2004.

Fujii, Y. and Satake, K.: Slip distribution and seismic moment of the 2010 and 1960 Chilean earthquakes inferred from tsunami waveforms and coastal geodetic data, Pure App. Geophys., 170, 1493-1509, doi:10.1007/s00024-012-0524-2, 2013.

Gelfenbaum, G., Apotsos, A, Stevens, A. W., and Jaffe, B.: Effects of fringing reefs on tsunami inundation: American Samoa, EarthSci. Rev., 107, 12-22, doi:10.1016/j.earscirev.2010.12.005, 2011.

Goff, J.: Evidence of a previously unrecorded local tsunami, 13 April 2010, Cook Islands: implications for Pacific Island countries, Nat. Hazards Earth Syst. Sci., 11, 1371-1379, doi:10.5194/nhess-11-1371-2011, 2011.

Goff, J., Chagué-Goff, C., and Terry, J. P.: The value of a Pacific-wide tsunami database for risk reduction - putting theory into practice. Geol. Soc. Spec. Publ. No 361, 209-220, doi:10.1144/SP361.17, 2012.

Goff, J., Lamarche, G., Pelletier, B., Chague-Goff, C., and Strotz, L.: Predecessors to the 2009 South Pacific tsunami in the Wallis and Futuna archipelago, Earth-Sci. Rev., 107, 91-106, 2011 a.
Goff, J., Chagué-Goff, C., Dominey-Howes, D., McAdoo, B., Cronin, S., Bonté-Grapetin, M., Nichol, S., Horrocks, M., Cisternas, M., Lamarche, G., Pelletier, B., Jaffe, B., and Dudley, W.: Palaeotsunamis in the Pacific, Earth-Sci. Rev., 107, 141-146, doi:10.1016/j.earscirev.2010.10.005, 2011b.

Greenslade, D. J. M., Simanjuntak, M. A., and Allen, S. C. R.: An enhanced tsunami scenario database: T2. ISSN: Centre for Australian Weather and Climate Research, Aust. Bureau Met. (CSIRO), Melbourne, Australia, CAWCR technical report: 014, 36 pp., ISSN: 1836-019X, ISBN: 9781921605376, 2009.

Hanks, T. C. and Kanamori, H.: A moment magnitude scale, J. Geophys. Res., 84, 2348-2350, 1979.

Hébert, H., Heinrich, P., Schindelé, F., and Piatanesi, A.: Far-field simulation of tsunami propagation in the Pacific Ocean: impact on the Marquesas Islands (French Polynesia), J. Geophys. Res., 106, 9161-9177, doi:10.1029/2000JC000552, 2001a.

Hébert, H., Piatanesi, A., Heinrich, P., Schindelé, F., and Okal, E.: Numerical modelling of the September 13, 1999 landslide and tsunami on Fatu Hiva Island (French Polynesia), Geophys. Res. Lett., 29, 122-1-122-4 doi:10.1029/2001GL01374, 2002.

Heinrich, P., Guibourg, S., and Roche, R.: Numerical modelling of the 1960 Chilean tsunami, Impact on French Polynesia, Phys. Chem. Earth, 21, 19-25, 1996.

Ioualalen, M., Pelletier, B., Watts, P., and Regnier, M.: Numerical modeling of the 26th November 1999 Vanuatu tsunami, J. Geophys. Res., 111, C06030, doi:10.1029/2005JC003249, 2006.

Jensen, P. D. (Lt.): Royal New Zealand Navy Littoral Warfare Support Group: Exercise Tropic Twilight 19-26 July 2011 - Report of Survey, 98 pp., and digital data, Surveyed by the Royal New Zealand Navy Deployable Hydrographic Survey Unit, Auckland, New Zealand, 2011.

Johnson, J. M. and Satake, K.: Source parameters of the 1957 Aleutian Earthquake from tsunami waveforms, Geophys. Res. Lett., 20, 1487-1490, 1993.

Johnson, J. M. and Satake, K.: Asperity distribution of the 1952 great Kamchatka earthquake and its relation to future earthquake potential in Kamchatka, Pure Appl. Geophys., 154, 541-553, 1999.

Johnson, J. M., Tanioka, Y., Ruff, L. J., Satake, K., Kanamori, H., and Sykes, L. R.: The 1957 Great Aleutian Earthquake, PAGEOPH., 142, 3-28, 1994.

Johnson, J. M., Satake, K., Holdahl, S. R., and Sauber, J.: The 1964 Prince William Sound earthquake: Joint inversion of tsunami and geodetic data, J. Geophys. Res.-Sol. Earth, 101, 523-532, 1996.

Kanamori, H.: The energy release of great earthquakes, J. Geophys. Res., 82, 2981-2987, 1977.

Kench, P. S., McLean, R. F., Brander, R. W., Nichol, S. L., Smithers, S. G., Ford, M. R., Parnell, K. E., and Aslam, M.: Geological effects of tsunami on mid-ocean atoll islands: The Maldives before and after the Sumatran tsunami, Geology, 34, 177-180, doi:10.1130/G21907.1, 2006.

Kench, P. S., Nichol, S. L., Smithers, S. G., McLean, R. F., and Brander, R. W.: Tsunami as agents of geomorphic change in mid-ocean reef islands, Geomorph., 95, 361-383, doi:10.1016/j.geomorph.2007.06.012, 2008.

Klostermann, L., Gischler, E., Storz, D., and Hudson, J. H.: Sedimentary record of late Holocene event beds in a mid-ocean atoll lagoon, Maldives, Indian Ocean: Poten- 
tial for deposition by tsunamis, Mar. Geol., 348, 37-43, doi:10.1016/j.margeo.2013.11.014, 2014

Kunkel, C. M., Hallberg, R. W., and Oppenheimer, M.: Coral reefs reduce tsunami impact in model simulations, Geophys. Res. Lett., 33, L23612, doi:10.1029/2006GL027892, 2006.

Kurita, T., Arakida, M., and Colombage, S. R. N.: Regional characteristics of tsunami risk perception among the tsunami affected countries in the Indian Ocean, J. Nat. Disast. Sci., 29, 29-38, 2007.

Lamarche, G., Pelletier, B., and Goff, J.: Impact of the 29 September 2009 South Pacific Tsunami on Wallis and Futuna, Mar. Geol., 271, 297-302, doi:10.1016/j.margeo.2010.02.012, 2010.

Lamarche, G., Popinet, S., Pelletier, B., Goff, J., Delaux, S., Mountjoy, J. J., and Bind, J.: Scenario-based numerical modelling and paleo-historic records of tsunami in Wallis and Futuna, Southwest Pacific, Nat. Hazards Earth Syst. Sci., 15, 1763-1784, doi:10.5194/nhess-15-1763-2015, 2015.

Lay, T., Ammon, C. J., Kanamori, H., Rivera, L., Koper, K. D., and Hutko, A. R.: The 2009 Samoa-Tonga great earthquake triggered doublet, Nature, 466, 964-968, 2010.

MacInnes, B. T., Weiss, R., Bourgeois, J., and Pinegina, T. K.: Slip distribution of the 1952 Kamchatka great earthquake based on near-field tsunami deposits and historical records, Bull. Seismol. Soc. Am., 100, 1695-1709, doi:10.1785/0120090376, 2010.

McLean, R.: Existing and proposed extension to gabion seawall protection in Tokelau: environmental impact assessment, South Pacific Regional Environmental Programme (SPREP) Reports and Studies no.62, SPREP, Apia, Western Samoa, 40 pp., ISBN 982-04-0047-3, 1993.

National Geophysical Data Center/World Data Service (NGDC/WDS): Global Historical Tsunami Database. National Geophysical Data Center, NOAA, doi:10.7289/V5PN93H7, 2016.

Okada, Y.: Surface deformation due to shear and tensile faults in a half-space, Bull. Seismol. Soc. Am., 75, 1135-1154, 1985.

Okal, E. A.: Seismic parameters controlling far-field tsunami amplitudes: A review, Nat. Hazards, 1, 67-96, 1988.

Okal, E. A. and Hébert, H.: Far-field simulation of the 1946 Aleutian tsunami, Geophys. J. Int., 169, 1229-1238, doi:10.1111/j.1365-246X.2007.03375.x, 2007.

Okal, E. A., Fritz, H. M., Synolakis, C. E., Borrero, J. C., Weiss, R., Lynett, P. J., Titov, V. V., Foteinis, S., Jaffe, B. E., Liu, P. L. F., and Chan, I. C.: Field Survey of the Samoa Tsunami of 29 September 2009, Seismol. Res. Lett., 81, 577-591, 2010.

Panda, N., Dawson, C., Zhang, Y., Kennedy, A. B., Westerink, J. J., and Donahue, A. S.: Discontinuous Galerkin methods for solving Boussinesq-Green-Naghdi equations in resolving non-linear and dispersive surface water waves, J. Comput. Phys., 273, 572588, 2014

Pelletier, B., Calmant, S., and Pillet, R.: Current tectonics of the Tonga-New Hebrides region, Earth Planet. Sc. Lett., 164, $263-$ 276, 1998

Pelletier, B., Regnier, M., Calmant, S., Pillet, R., Cabioch, G., Lagabrielle, Y., Bore, J.-M., Caminade, J.-P., Cristopher, I., and Temakon, S.: Le séisme d'Ambrym-Pentecôte (Vanuatu) du 26 novembre 1999: données préliminaires sur la séismicité, le tsunami et les déplacements associés, Comptes Rend. Acad. Sci., Paris, 2, 331, 21-28, 2000.
Popinet, S.: Gerris: a tree-based adaptive solver for the incompressible Euler equations in complex geometries, J. Comput. Phys., 190, 572-600, 2003.

Popinet, S.: Quadtree-adaptive tsunami modelling, Ocean Dynam., 61, 1261-1285, 2011.

Popinet, S.: Adaptive modelling of long-distance wave propagation and fine-scale flooding during the Tohoku tsunami, Nat. Hazards Earth Syst. Sci., 12, 1213-1227, doi:10.5194/nhess-121213-2012, 2012.

Popinet, S.: Basilisk, http://basilisk.fr (last access: 26 February 2016), 2014.

Popinet, S.: A quadtree-adaptive multigrid solver for the SerreGreen-Naghdi equations, J. Comput. Phys., 302, 336-358, doi:10.1016/j.jcp.2015.09.009, 2015

Rabinovich, A. B. and Thomson, R. E.: The 26 December 2004 Sumatra tsunami: Analysis of tide gauge data from the world ocean Part 1. Indian Ocean and South Africa, Pure Appl. Geophys., 164, 261-308, doi:10.1007/s00024-006-0164-5, 2007.

Rabinovich, A. B., Lobkovsky, L. I., Fine, I. V., Thomson, R. E., Ivelskaya, T. N., and Kulikov, E. A.: Near-source observations and modeling of the Kuril Islands tsunamis of 15 November 2006 and 13 January 2007, Adv. Geosci., 14, 105-116, doi:10.5194/adgeo-14-105-2008, 2008.

Régnier, M., Calmant, S., Pelletier, B., Lagabrielle, Y., and Cabioch, G.: The $M_{\mathrm{w}} 7.51999$ Ambrym earthquake, Vanuatu: A back arc intraplate thrust event, Tectonics, 22, 1034, doi:10.1029/2002TC001422, 2003.

Sahal, A., Pelletier, B., Chatelier, J., Lavigne, F., and Schindelé, F.: A catalog of tsunamis in New Caledonia from 28 March 1875 to 30 September 2009, Compt. Rend. Geosci., 342, 434-447, 2010.

Shao, G., Li, X., Ji, C., and Maeda, T.: Focal mechanism and slip history of the $2011 M_{\mathrm{W}} 9.1$ off the Pacific coast of Tohoku Earthquake, constrained with teleseismic body and surface waves, Earth Planet. Space, 63, 559-564, 2011.

Sladen, A., Hébert, H., Schindelé, F., and Reymond, D.: Evaluation of far-field tsunami hazard in French Polynesia based on historical data and numerical simulations, Nat. Hazards Earth Syst. Sci., 7, 195-206, doi:10.5194/nhess-7-195-2007, 2007.

Tinti, S., Tonini, R., Bressan, L., Armigliato, A., Gardi, A., Guillande, R., Valencia, N., and Scheer, S.: Handbook of tsunami hazard and damage scenarios: SCHEMA (Scenarios for Hazardinduced Emergencies Management), Project no. 030963, Specific Targeted Research Project, Space Priority, Joint Research Centre Scientific and Technical Reports, EUR 24691 EN, Luxembourg, 41 pp., ISBN 978-92-79-19062-9, 2011.

Wells, D. L. and Coppersmith, K. J.: New empirical relationships among magnitude, rupture length, rupture width, rupture area, and surface displacement, Bull. Seismol. Soc. Am., 84, 974 $1002,1994$.

Wesson, R. L., Boyd, O. S., Mueller, C. S., Bufe, C. G., Frankel, A. D., and Petersen, M. D.: Revision of time-independent probabilistic seismic hazard maps for Alaska. USGS Open File Report 2007-1043, 2007.

Woodroffe, C. D.: Reef-island topography and the vulnerability of atolls to sea-level rise, Global Planet. Change, 62, 77-96, doi:10.1016/j.gloplacha.2007.11.001, 2008. 